\title{
Land-Use Types Combined with Plant Species Alter Soil Fungal Community and Functional Guilds in the Eastern Mountainous Region of Liaoning Province, China
}

\author{
Qian Zhang ${ }^{1 \#}$, Jiaojiao Deng ${ }^{1,2 \#, ~ W e n x u ~ Z h u ~}{ }^{1,3}$, Shijun Wu', Xuejiao Bai ${ }^{1,3}$, \\ Yongbin Zhou ${ }^{1,2,3}$, You Yin ${ }^{1,3 *}$ \\ ${ }^{1}$ College of Forestry, Shenyang Agricultural University, Shenyang 110161, China \\ ${ }^{2}$ College of Land and Environment, Shenyang Agricultural University, Shenyang 110866, China \\ ${ }^{3}$ Research Station of Liaohe-River Plain Forest Ecosystem, Chinese Forest Ecosystem Research Network (CFERN), \\ Shenyang Agricultural University, Tieling 112000, China
}

Received: 26 February 2020

Accepted: 26 April 2020

\begin{abstract}
Land-use changes or plant species have a profound impact on soil chemical properties, but under their combined action, little is known about the changes in soil fungal communities and functional guilds. We investigated the effects of different land-use types and plant species on the fungal community and functional guilds in the eastern mountainous area of Liaoning Province, including natural secondary forests (Quercus mongolica, shrub wood), plantation forests (Larix gmelini, Pinus koraiensis), and farmland (Zea mays). Fungal community diversity and composition were analyzed using Illumina Miseq high-throughput sequencing. Responses of soil fungal communities to environmental factors were assessed through canonical correlation analysis (CCA) and Pearson correlation analysis. The results illustrated that LG, and PK did not improve soil conditions to the same degree as QM. In addition, compared to SW, ZM decreased soil fertility. The dominant phyla were Ascomycota and Basidiomycota, with average relative abundances of $55.3 \%$ and $31.78 \%$, respectively. The phylum Ascomycota was the dominant group in QM, SW, and ZM, while, Basidiomycota dominated in LG, and PK. Heatmap $(P<0.05)$ and NMDS (stress $=0.07)$ plots showed that soil fungal communities from LG, PK, and ZM tended to be separated from those of QM and SW. Additionally, soil fungal community functions from QM, SW, and LG were separated from those of PK and ZM. Both analyses demonstrated that different land-use types and plant species had significantly different impacts on the soil fungal communities. Canonical correlation analysis suggested that soil $\mathrm{pH}$ value, $\mathrm{NH}_{4}^{+}-\mathrm{N}$, and $\mathrm{NO}_{3}{ }^{-}$ $-\mathrm{N}$ contents were the main factors affecting the soil fungal community diversity and composition. Our
\end{abstract}

\#The authors contributed equally to this work.

*e-mail: 1993500012@syau.edu.cn 
results demonstrated that fungal community diversity, composition, and functional groups significantly differed among the three different land use types, so were differences in different plant species under the same land-use type.

Keywords: the eastern mountainous region of Liaoning Province, land use types, plant species, fungal community, functional guilds

\section{Introduction}

Forest biodiversity and ecosystem services are of global importance [1]. However, during the past 100 years, an increasing number of natural forests have been under constant threat of deforestation as a consequence of economic development and agricultural expansion in China and other countries [2-4]. There are growing evidences that that land use conversion is a key component of global changes and strongly affects many ecosystem services and functions in terrestrial ecosystems [5-9], such as a noticeable loss of plant and animal biodiversity [10-11], erosion and nutrient leaching [12], reduction in soil carbon stocks and soil nitrogen availability [13-14], soil degradation [15], and increases in greenhouse gas emissions [16]. Converting natural and semi-natural vegetation into agricultural fields is currently the most significant land use change on a global scale [17]. So far, over $38 \%$ of all pristine forests worldwide have been converted to managed systems, such as agricultural land and plantation forests [18], a phenomenon that is particularly prevalent in South America, Africa, and Asia [19]. Land-use conversion drastically modifies vegetation type, which is one of the major drivers that influence soil environmental conditions [20-21], mainly in terms of soil physicalchemical properties [22], such as soil temperature, water balance, $\mathrm{pH}$, carbon and nutrient dynamics [2324], as well as soil enzymatic activities [25], which can directly affect soil microbial communities [2628]. Soil microbial community diversity and structure are sensitive indicators of soil health and quality and hence rapidly respond to land-use conversions [29]. Any changes in soil nutrients and environmental quality can be predicted through the diversity and variability of soil microorganisms [30].

Microorganisms occupy an important position in terrestrial ecosystems, regulating biogeochemical cycling of nutrients [31-33], and affecting vegetation growth [34] and ecosystem stability [35]. Fungi, as indicators of ecosystem health and important decomposers, are ubiquitous inhabitants of soil ecosystems; they are crucial for ecosystem functioning [36] and strongly drive abiotic soil conditions [37-38]. Soil fungi have a high plasticity and can take various forms to respond to adverse or unfavorable conditions [39]. They can decompose plant residues and complex compounds such as lignin, hemicellulose, and cellulose, thereby releasing nutrients for the vegetation [40]. Fungi show a particularly high sensitivity to shifts in vegetation because of their close associations with plants [41]. Previous studies have suggested that land use change can affect the microbial decomposition of litter and SOM, and against this background, changes in soil fungal diversity can influence soil ecological processes such as nutrient cycling [42-43] and gas release [4446] in terrestrial ecosystems. In this sense, the impact of land use conversion on soil fungal communities is receiving increasing attention [47], and it is crucial to research the fungal diversity and community structure to increase our understanding of the functions and processes of ecosystems and to evaluate ecosystem services.

The effects of conversion from natural forests into planation forests [48-49] and agriculture [50] on soil physicochemical characteristics in the tropical forests have been comprehensively investigated. In addition, previous studies have demonstrated that microbial biomass, microbial activity [51], and microbial communities can differ between forested and agricultural lands [52-54]. Further, numerous studies have quantified the responses of bacterial communities to land use changes in tropical systems [55-58]. However, the changes in the soil fungal community diversity and structure as a consequence of converting natural secondary forests into plantations and farmland have been less studied, especially in temperate ecosystems. In particular, the effects of land use conversion on soil fungal community functional guilds have not yet been sufficiently assessed. Nevertheless, the obtain relevant information on fungal responses to changes in the soil environment and to adequately predict ecosystem stability and services, the consequences of land use conversion for soil fungal community diversity, structure, and functional guilds should be investigated. In addition, elucidating the changes of soil nutrient and fungal community structure and function in different land use types and vegetation types is of great significance for selecting suitable vegetation for restoration.

In this context, we elucidated the responses of the soil fungal communities relevant to land-use conversion and compared, soil fungal community diversity, structure, and functional guilds from three different land use types, including natural secondary forests (QM: Quercus mongolica, SW: shurdwood), plantation forests (LG: Larix gmelini, PK: Pinus koraiensis), and farmland (ZM: Zea mays) in the eastern mountainous region of Liaoning Province. For this, we used internal transcribed spacer (ITS) ribosomal DNA (rDNA) 


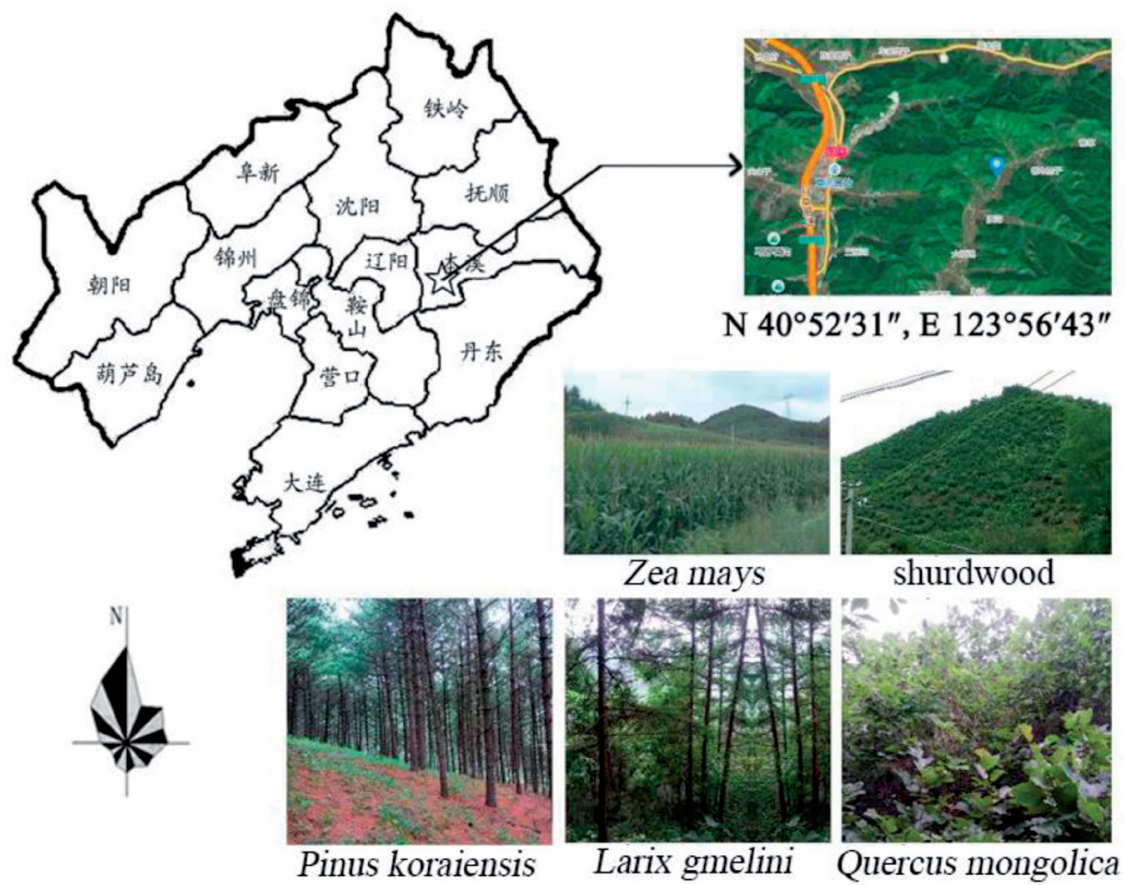

Fig. 1. Sampling sites.

via Illumina Miseq high-throughput sequencing and analyzed soil characteristics, fungal community diversity, composition, and functional guilds across three different land use types. We further tested the hypotheses that 1) the conversion of secondary forests to different plantation forests and agricultural land significantly alter soil characteristics; 2) the conversion of secondary forests to different plantation forests and agricultural land would significantly alter the fungal community diversity, structure, and function; 3) land use types and plant species changes generated changes in soil chemical properties, influencing the composition of the soil fungal communities. Monitoring soil fungal community composition and function changes under different land use types could provide a theoretical basis for the restoration of degraded soil ecosystems and for the sustainable management of plantations.

\section{Materials and Method Sites Description}

The research area is located in the experimental forest farm of the Liaoning Institute of Forest Management $\left(40^{\circ} 52^{\prime} 31^{\prime \prime} \mathrm{N}, 123^{\circ} 56^{\prime} 43^{\prime \prime} \mathrm{E}\right)$, in the hilly land of the eastern mountainous region of Liaoning Province, China. The region is typically a temperate continental monsoon climate with a mean annual temperature of $6.5^{\circ} \mathrm{C}$, an annual average precipitation of $926.3 \mathrm{~mm}$, and an annual average evaporation of $1,056 \mathrm{~mm}$. The soil type is characterized as Eutrochrepts, according to the USDA system [59], with a thickness of $50 \mathrm{~cm}$ and frozen to a depth of $150 \mathrm{~cm}$. To date, numerous secondary forests have been transformed into plantation forests due to the increasing demand for timber, some of which were reclaimed as farmland. Currently, land

Table 1. Sample information.

\begin{tabular}{|c|c|c|c|c|c|c|}
\hline Plant species & $\begin{array}{c}\text { Forest } \\
\text { age }\end{array}$ & $\begin{array}{c}\text { Stand density } \\
\left(\text { ind } \cdot \mathrm{hm}^{-1}\right)\end{array}$ & $\begin{array}{c}\text { Crown } \\
\text { density }\end{array}$ & $\begin{array}{c}\text { Mean DBH } \\
(\mathrm{cm})\end{array}$ & $\begin{array}{c}\text { Herb } \\
\text { coverage }\end{array}$ & Main herb under the forest \\
\hline $\begin{array}{c}\text { Quercus } \\
\text { mongolica }\end{array}$ & 61 & 2357 & $90 \%$ & 20.18 & $60 \%$ & $\begin{array}{c}\text { Vicia unijuga, Gueldenstaedtia verna, Atractylodes } \\
\text { Lancea, Schisandra chinensis, Asparagus } \\
\text { oligoclonos, Corylus mandshurica, Celastrus } \\
\text { orbiculatus, Lespedeza bicolor }\end{array}$ \\
\hline Larix gmelini & 40 & 2100 & $80 \%$ & 12.68 & $90 \%$ & $\begin{array}{c}\text { Rubus crataegifolius, Rubus idaeus, Asparagus } \\
\text { oligoclonos, Schisandra chinensis, Athyrium } \\
\text { brevifrons, Menispermum dauricum }\end{array}$ \\
\hline $\begin{array}{c}\text { Pinus } \\
\text { koraiensis }\end{array}$ & 61 & 1800 & $70 \%$ & 21.94 & $30 \%$ & $\begin{array}{c}\text { Polygonatum odoratum, Vitis amurensis, } \\
\text { Athyrium brevifrons, Menispermum dauricum, } \\
\text { Vicia unijuga, Asparagus oligoclonos, Guelden- } \\
\text { staedia verna, Atractylodes Lancea, Schisandra } \\
\text { chinensis, Asparagus oligoclonos }\end{array}$ \\
\hline
\end{tabular}


use patterns mainly include natural secondary forests, plantations, and agricultural lands (Fig. 1; Table 1). Zea mays was cultivated for 5 years, before which the dominant vegetation type was shrubwood. The field management in the area is extensive, with no irrigation and straw returning [60].

\section{Sample Collection}

In July 2017, we sampled among five sites with uniform conditions (same slope, slope aspect and altitude), including shrub wood, Quercus mongolica, Pinus koraiensis, Larix gmelini, and Zea mays. Soil samples were collected from three districts $(20 \mathrm{~m} \times$ $20 \mathrm{~m}$ ) with three independent replicates in each site. An "S" strip sampling method was used to ensure the representativeness of soil samples in each district. Sampling was performed with a soil auger $(10 \mathrm{~cm}$ deep, $8 \mathrm{~cm}$ in diameter) at a depth of $10 \mathrm{~cm}$, with a total number of 15 samples. All soil samples were well mixed, and sieved to pass a 2-mm sieve; roots and other debris were removed. The prepared soil samples for the determination of soil properties was air-dried at room temperature, and the rest for high-throughput sequencing was stored at $-80^{\circ} \mathrm{C}$.

\section{Determination of Soil Chemical Properties}

Soil $\mathrm{pH}$ was measured in a soil-water $(1: 5 \mathrm{w} / \mathrm{v})$ suspension for $30 \mathrm{~min}$ using a $\mathrm{pH}$ meter after shaking [61]. The concentrations of soil total $\mathrm{C}$ and total $\mathrm{N}$ were determined by an Elemental Analyzer (Elementar, Germany) [62]. Alkaline diffusion method was adopted for the determination of available nitrogen (AN) [63]. Additionally, the contents of ammonium nitrogen $\left(\mathrm{NH}_{4}{ }^{+} \mathrm{N}\right)$ and nitrate nitrogen $\left(\mathrm{NO}_{3}^{-}-\mathrm{N}\right)$ were measured using an AA3 continuous flow analytical system with $1 \mathrm{M} \mathrm{KCl}$ extraction (AA3, Germany) [63].

\section{Soil DNA Extraction}

The FastDNA SPIN extraction kits (MP Biomedicals, Santa Ana, CA, USA) was used to extract total genomic DNA from $0.5 \mathrm{~g}$ soil, following the manufacturer's instructions. The quantity and quality of the extracted DNAs were measured using a NanoDrop ND-1000 spectrophotometer (Thermo Fisher Scientific, Waltham, MA, USA) and agarose gel electrophoresis, respectively.

\section{ITS rDNA High Throughput Sequencing}

The PCR amplification of the fungal ITS rDNA region was performed using the primers ITS1F (5'-CTTGGTCATTTAGAGGAAGTAA-3') and ITS2 (5'-GCTGCGTTCTTCATCGATGC-3') [64]. A total of $25 \mu 1$ of PCR amplification reaction for each DNA sample contained $5 \mu$ of Q5 reaction buffer and Q5 High-Fidelity GC buffer, respectively, $1 \mu$ l of ITS1F and ITS2 primer (10 uM), respectively, DNA template (40-50 ng) $2 \mu \mathrm{l}$, dNTPs $(2.5 \mathrm{mM}) 2 \mu \mathrm{l}$, Q5 high-fidelity DNA polymerase $(5 \mathrm{U} / \mu \mathrm{l}) 0.25 \mu \mathrm{l}$, and $\mathrm{ddH}_{2} \mathrm{O} 8.75 \mu \mathrm{l}$. Cycling conditions were pre-denaturation at $98^{\circ} \mathrm{C}$ for 5 min, 25 cycles of denaturation at $98^{\circ} \mathrm{C}$ for 15 $\mathrm{s}$, annealing at $52^{\circ} \mathrm{C}$ for $30 \mathrm{~s}$, extend at $72^{\circ} \mathrm{C}$ for $30 \mathrm{~s}$, followed by extending at $72^{\circ} \mathrm{C}$ for $5 \mathrm{~min}$. PCR amplicons were purified using Agencourt AMPure Beads (Beckman Coulter, Indianapolis, IN) and quantified with the PicoGreen dsDNA Assay Kit (Invitrogen, Carlsbad, CA, USA) [64-65]. Pair-end $2 \times 300 \mathrm{bp}$ sequencing was performed using the Illumina MiSeq platform with MiSeq Reagent Kit v3 (Shanghai Personal Biotechnology Co., Ltd, Shanghai, China).

\section{Bioinformatics and Statistical Analysis}

This project used the Illumina MiSeq platform for paired-by-end sequencing of community DNA fragments. Sequencing raw data saved in FASTQ format and the raw Q30 rate in our study was $91.97 \%$. The raw data obtained from Illumina sequencing were merged and analyzed using the QIIME software (Quantitative Insights Into Microbial Ecology, v1.8.0, http://qiime.org/) [66] and the UPARSE (v5.2.236, http://www.drive5.com/usearch/) pipeline [67]. In order to integrate the original double-end sequencing data, the double-ended sequence of FASTQ format was first screened by mass using the sliding window method with the window size of $10 \mathrm{bp}$ and the step size of $1 \mathrm{bp}$. Moving from the first base position at the 5' end, the average mass of the base in the window should be great than Q20 (ie, the average base sequencing accuracy $\geq 99 \%$ ). The sequence with an average quality value below Q20 in the first window need to be truncated, and the truncated sequence length was greater than or equal to $150 \mathrm{bp}$ and no ambiguous base $\mathrm{N}$ was allowed. Subsequently, the FLASH software (v1.2.7, http://ccb.jhu.edu/software/ FLASH/) [68] was used to pair and connect the double-ended sequences that pass through the initial mass screening according to the overlapping bases. The overlapping base length of Read 1 and Read 2 sequences was $\geq 10$ bp. Finally, the concatenated sequence recognition was completely assigned to the corresponding sample according to the barcode sequence corresponding to each sample, thereby obtaining the effective sequence of each sample. We uploaded all raw sequences to the NCBI Sequence Read Archive under submission number SUB4745583 and BioProject number PRJNA503702. OTU divided by $97 \%$ sequences similarity using the UCLUST sequence alignment tool [69]. Then the most abundant sequence in each OTU was selected as the representative sequence of the OTU. Rare OTUs and the OTUs with abundance values below $0.001 \%$ of the total sequencing of the entire sample were removed for subsequent analysis [70]. We classified each OTU into 
Table 2. Soil chemical characteristics under different sites.

\begin{tabular}{|c|c|c|c|c|c|c|c|}
\hline $\begin{array}{c}\text { Plant } \\
\text { species }\end{array}$ & $\mathrm{pH}$ value & $\begin{array}{c}\text { Total C } \\
\left(\mathrm{g} \cdot \mathrm{kg}^{-1}\right)\end{array}$ & $\begin{array}{c}\text { Total N } \\
\left(\mathrm{g} \cdot \mathrm{kg}^{-1}\right)\end{array}$ & $\mathrm{C} / \mathrm{N}$ ratio & $\begin{array}{c}\text { Available N } \\
\left(\mathrm{mg} \cdot \mathrm{kg}^{-1}\right)\end{array}$ & $\begin{array}{c}\mathrm{NH}_{4}^{+}-\mathrm{N} \\
\left(\mathrm{mg}^{+} \cdot \mathrm{kg}^{-1}\right)\end{array}$ & $\begin{array}{c}\mathrm{NO}_{3}^{-}-\mathrm{N} \\
\left(\mathrm{mg}^{-1} \cdot \mathrm{kg}^{-1}\right)\end{array}$ \\
\hline QM & $5.99 \pm 0.15 \mathrm{ab}$ & $57.74 \pm 15.68 \mathrm{a}$ & $4.40 \pm 1.11 \mathrm{a}$ & $13.09 \pm 0.39 \mathrm{a}$ & $33.63 \pm 7.19 \mathrm{a}$ & $4.42 \pm 0.50 \mathrm{~b}$ & $17.09 \pm 3.69 \mathrm{ab}$ \\
\hline $\mathrm{SW}$ & $6.29 \pm 0.16 \mathrm{a}$ & $38.27 \pm 5.49 \mathrm{~b}$ & $2.79 \pm 0.42 \mathrm{~b}$ & $13.71 \pm 0.31 \mathrm{a}$ & $23.50 \pm 5.87 \mathrm{~b}$ & $3.78 \pm 0.15 \mathrm{~b}$ & $9.58 \pm 0.68 \mathrm{~b}$ \\
\hline $\mathrm{LG}$ & $5.57 \pm 0.24 \mathrm{c}$ & $52.24 \pm 3.36 \mathrm{ab}$ & $3.89 \pm 0.27 \mathrm{a}$ & $13.43 \pm 0.20 \mathrm{a}$ & $32.05 \pm 3.61 \mathrm{a}$ & $6.33 \pm 1.44 \mathrm{a}$ & $26.44 \pm 9.88 \mathrm{a}$ \\
\hline PK & $5.54 \pm 0.11 \mathrm{c}$ & $20.08 \pm 4.01 \mathrm{c}$ & $1.53 \pm 0.32 \mathrm{c}$ & $13.24 \pm 1.88 \mathrm{a}$ & $12.96 \pm 2.56 \mathrm{c}$ & $7.68 \pm 1.45 \mathrm{a}$ & $24.17 \pm 2.81 \mathrm{a}$ \\
\hline $\mathrm{ZM}$ & $5.85 \pm 0.16 \mathrm{bc}$ & $17.46 \pm 2.33 \mathrm{c}$ & $1.31 \pm 0.20 \mathrm{c}$ & $13.39 \pm 0.28 \mathrm{a}$ & $11.90 \pm 1.33 \mathrm{c}$ & $3.94 \pm 0.77 \mathrm{~b}$ & $19.53 \pm 6.47 \mathrm{ab}$ \\
\hline
\end{tabular}

$\mathrm{n}=3$. Different lowercase letters in each column indicate a significant difference $(P<0.05)$. QM: Quercus mongolica; SW: Shrub wood; LG: Larix gmelini; PK: Pinus koraiensis; ZM: Zea mays.

an ecological guild using FUNGuild [71] to determine specific functional groups of fungi among different samples.

Venn diagrams were used to visualize the shared and unique OTUs among samples using the R package with the "VennDiagram", based on the occurrence of OTUs across samples. The heatmap representation of the top 50 relative abundance of fungal genera, and the fungal functions among samples were performed using the R packages (v 3.4.4) with "gplot" and "pheatmap". Beta diversity analysis was performed to investigate the structural variation of fungal communities across samples, using nonmetric multidimensional scaling (NMDS) based on unweighted Unifrac distance metrics. The linear discriminant analysis (LDA) effect size (LEfSe) was fulfilled to detect differentially abundant taxa across groups using the default parameters. Oneway analysis of variance (ANOVA) was conducted using the software package SPSS 19.0 (SPSS Inc., USA). Soil chemical characteristics, fungal total relative abundances, and alpha diversity indices under different land-use types were compared using the LSD test. Pearson correlation analysis was used to calculate the correlations between alpha diversity indices and soil characteristics. Canonical correspondence analysis (CCA), which was performed by functions in the Cannon 4.5, was used to evaluate the linkages between dominant fungal groups related to the measured soil environmental factors.

\section{Results}

\section{Soil Chemical Characteristics in Different Sites}

Soil nutrient levels can be reflected by basic soil chemical properties, and significant differences in soil chemical characteristics among sites were observed (Table 2). The soil $\mathrm{pH}$ value ranged from 5.54 to 6.29 in all sites, with the highest level in SW with 6.29, followed by $\mathrm{QM}, \mathrm{LG}, \mathrm{PK}$, and $\mathrm{ZM}(P<0.05)$. No significant differences in soil $\mathrm{C} / \mathrm{N}$ among the different samples were observed, and soil $\mathrm{C} / \mathrm{N}$ varied from 13.09 to 13.71 . In terms of natural secondary forest, the contents of total $\mathrm{C}$, total $\mathrm{N}$, and available $\mathrm{N}$ in $\mathrm{SW}$ were $38.27 \mathrm{~g} \cdot \mathrm{kg}^{-1}, 2.79 \mathrm{~g} \cdot \mathrm{kg}^{-1}$, and $23.50 \mathrm{mg} \cdot \mathrm{kg}^{-1}$, respectively. While, the QM stand had the highest total $\mathrm{C}$, total $\mathrm{N}$ and available $\mathrm{N}$ values with $57.74 \mathrm{~g} \cdot \mathrm{kg}^{-1}, 4.40 \mathrm{~g} \cdot \mathrm{kg}^{-1}$, and $33.63 \mathrm{mg} \cdot \mathrm{kg}^{-1}$, respectively, significantly higher than those of SW, surprisingly, without a distinct difference to LG; however, the values were significantly higher than in PK $(P<0.05)$. Compared to the site $\mathrm{SW}$, the agricultural soils exhibited a reduction in soil total $\mathrm{C}$, total $\mathrm{N}$, and available $\mathrm{N}$. The contents of $\mathrm{NH}_{4}^{+}-\mathrm{N}$ in $\mathrm{LG}$ and PK were $6.33 \mathrm{mg} \cdot \mathrm{kg}^{-1}$ and $7.68 \mathrm{mg} \cdot \mathrm{kg}^{-1}$, respectively, and significantly higher than in QM, SW, and ZM. The contents of $\mathrm{NO}_{3}^{-}-\mathrm{N}$ in the different sites decreased in the order of $\mathrm{LG}>\mathrm{PK}>\mathrm{ZM}>\mathrm{QM}>\mathrm{SW}$, with the lowest level of $9.58 \mathrm{mg} \cdot \mathrm{kg}^{-1}$ (Table 2).

Table 3. Soil fungal diversity indices of different sites.

\begin{tabular}{|c|c|c|c|c|c|}
\hline Plant species & No. of sequences & Shannon index & Chao1 index & ACE index & Simpson index \\
\hline QM & 49878 & $7.30 \pm 0.13 \mathrm{a}$ & $870.63 \pm 170.47 \mathrm{a}$ & $882.80 \pm 181.64 \mathrm{a}$ & $0.968 \pm 0.011 \mathrm{a}$ \\
\hline SW & 36900 & $7.33 \pm 0.76 \mathrm{a}$ & $792.29 \pm 19.79 \mathrm{ab}$ & $791.63 \pm 18.81 \mathrm{ab}$ & $0.964 \pm 0.024 \mathrm{a}$ \\
\hline LG & 62011 & $5.82 \pm 0.93 \mathrm{c}$ & $529.62 \pm 128.40 \mathrm{c}$ & $531.75 \pm 126.12 \mathrm{c}$ & $0.918 \pm 0.044 \mathrm{~b}$ \\
\hline PK & 58994 & $6.09 \pm 0.47 \mathrm{bc}$ & $611.29 \pm 50.08 \mathrm{bc}$ & $621.30 \pm 45.22 \mathrm{bc}$ & $0.954 \pm 0.012 \mathrm{ab}$ \\
\hline ZM & 58934 & $6.94 \pm 0.41 \mathrm{ab}$ & $652.87 \pm 95.52 \mathrm{bc}$ & $655.14 \pm 99.62 \mathrm{bc}$ & $0.973 \pm 0.009 \mathrm{a}$ \\
\hline
\end{tabular}

Different lowercase letters within same column indicate significant difference at $P<0.05$ level (n=3). QM: Quercus mongolica; SW: Shrub wood; LG: Larix gmelini; PK: Pinus koraiensis; ZM: Zea mays. 


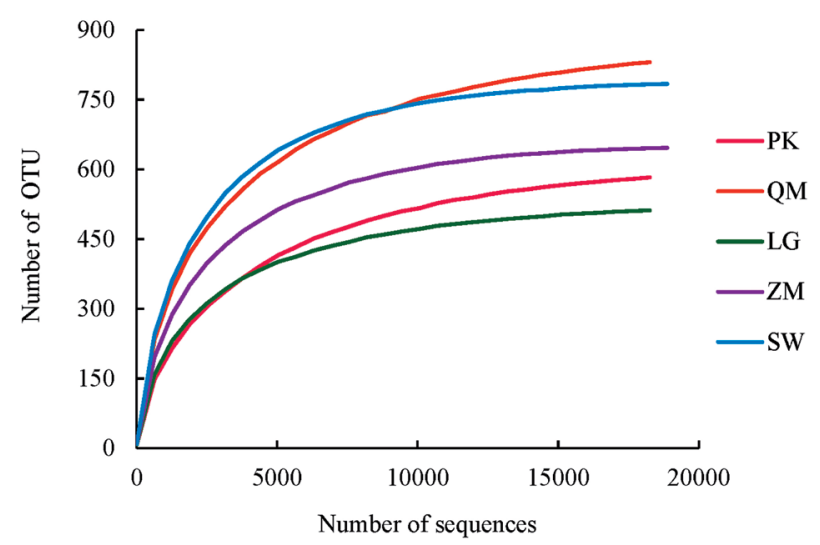

Fig. S1. Rarefaction curves of ITS rDNA for high throughput sequencing of fungus under different treatments. QM: Quercus mongolica; SW: Shrub wood; LG: Larix gmelini; PK: Pinus koraiensis; ZM: Zea mays.

\section{Soil Fungal Diversity in Different Sites}

A total of 800,155 sequences, targeting the ITS gene, were obtained from the 15 soil samples using Illumina MiSeq sequencing, ranging from 36,900 to 62,011 reads per sample (Table 3 ). At the $3 \%$ dissimilarity level (Supplement Fig. 1), the curve tended to flatten with an increasing number of measured sequences, indicating that most of the sample information was obtained and that the information adequately reflected the fungal community composition of the soil. Venn diagrams were used to compare the shared and unique OTUs between fungal communities among the samples. PK, LG, QM, SW, and ZM fungal communities had 107 shared OTUs and 457, 410, 591, 641, and 801

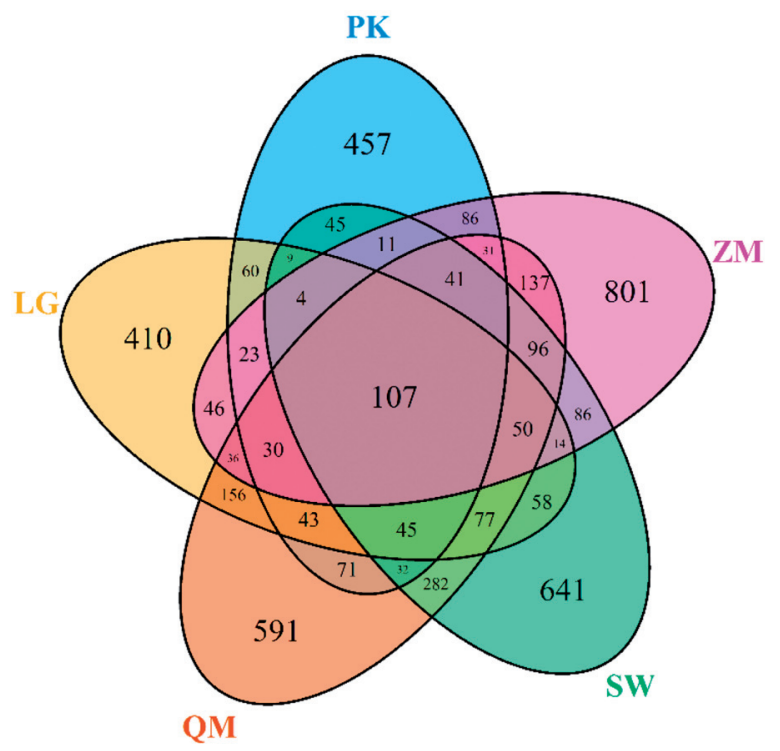

Fig. 2. Venn diagram. QM: Quercus mongolica; SW: Shrub wood; LG: Larix gmelini; PK: Pinus koraiensis; ZM: Zea mays. unique OUTs, respectively (Fig. 2). The unique OTUs accounted for $41.7 \%, 35.1 \%, 32.4 \%, 40.1 \%$, and $50.1 \%$ of the total detected OTUs in PK, LG, QM, SW and $\mathrm{ZM}$, respectively.

Fungal richness and evenness were estimated by Shannon, Simpson, Chaol, and ACE indices. Among the different sites, the average values of Shannon index, Chaol index, ACE index, and Simpson index in QM were 7.30, 870.63, 882.80, and 0.968, respectively, significantly higher than in PK, and LG. Additionally, it is found that PK exhibited higher Shannon, Chaol, ACE, and Simpson indices than LG. While, compared to the SW, the agricultural soils exhibited a reduction in soil fungal Shannon index, Chaol index, and ACE index, with 6.94, 652.87, and 655.14, respectively. Pearson correlation analysis showed that the soil $\mathrm{pH}$ had a positive relationship with Chaol index $(\mathrm{r}=0.56$, $P<0.05)$, ACE index $(\mathrm{r}=0.54, P<0.05)$, and Shannon index $(\mathrm{r}=0.64, P<0.05)$. While, the content of $\mathrm{NO}_{3}{ }^{-}-\mathrm{N}$ had a negative relationship with Chaol index $(\mathrm{r}=-0.58$, $P<0.05)$, ACE index $(\mathrm{r}=-0.57, P<0.05)$, and Shannon index $(\mathrm{r}=-0.53, P<0.05)$. The Shannon index $(\mathrm{r}=-0.84$, $P<0.01)$, Chaol index $(\mathrm{r}=-0.58, P<0.05)$, ACE index $(\mathrm{r}=-0.55, P<0.05)$, and Simpson index $(\mathrm{r}=-0.61$, $P<0.05)$ exhibited a negative correlation with the content of $\mathrm{NH}_{4}^{+}-\mathrm{N}$ (Table 4).

\section{Soil Fungal Community Composition under Different Sites}

Based on the RDP database, all efficient sequences from the five samples were classified from phylum to genus. The obtained 800,155 fungal ITS sequences were categorized as 8 phyla, 295 families, and over 300 genera, demonstrating abundant fungal communities in this ecosystem. There were significant differences in

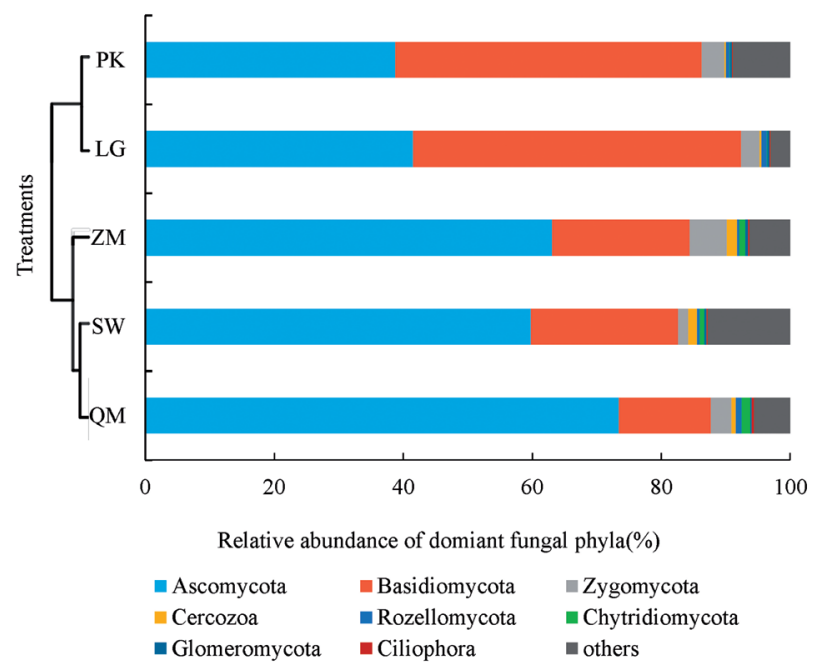

Fig. 3. The relative abundances of major taxonomic groups at the phylum level for fungi across five sites. QM: Quercus mongolica; SW: Shrub wood; LG: Larix gmelini; PK: Pinus koraiensis; ZM: Zea mays. 


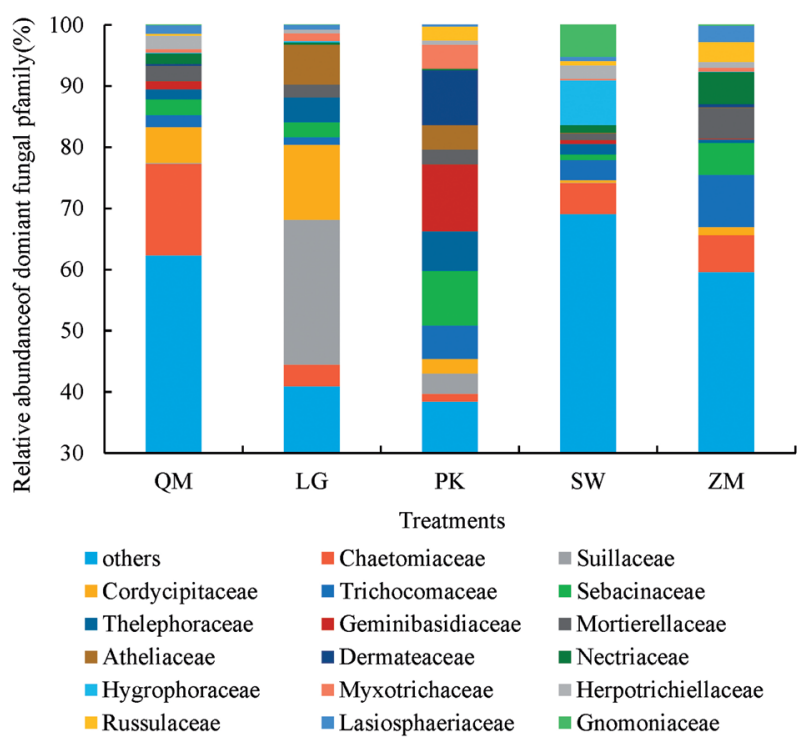

Fig. S2. The relative abundances of major taxonomic groups at the family level for fungi across five sites. QM: Quercus mongolica; SW: Shrub wood; LG: Larix gmelini; PK: Pinus koraiensis; ZM: Zea mays.

fungal community abundance at different phylogenetic levels. The majority of dominant fungal phylum across all soil samples belonged to Ascomycota, with a mean relative abundance ranging from 38.73\% to $73.40 \%$, followed by Basidiomycota $(14.30 \%$ to $50.91 \%$ ), and Zygomycot (1.56\% to 5.84\%) (Fig. 3). The relative abundances of the minor phyla Cercozoa, Rozellomycota, Chytridiomycota, Glomeromycota, and Ciliophora were all below $1 \%$. In addition, numerous sequences could not be classified into known fungi, with relative abundances varying from $3.02 \%$ to $12.82 \%$. The QM had the highest abundance of Ascomycota (73.40\%), and the lowest abundance of Basidiomycota (14.30\%). The phylum Ascomycota was the dominant group in QM, SW, and ZM, while, Basidiomycota dominanted in LG and PK (Fig. 3). In order to better illustrate the difference between natural secondary forests and managed systems, a cluster tree was adopted. The results clarified that soil fungal community at the phylum could be divided into two clusters, including QM, SW, plus ZM, and PK, plus LG.

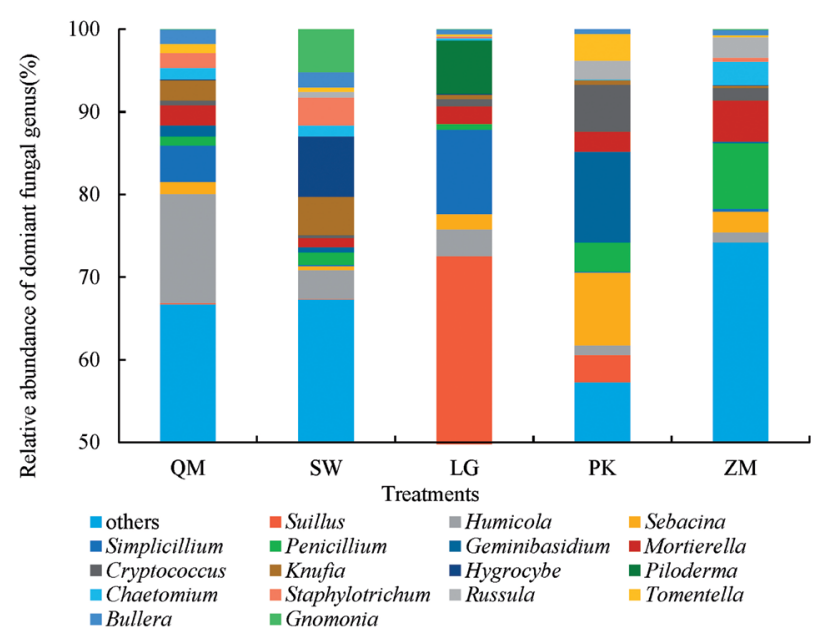

Fig. 4 The relative abundances of major taxonomic groups at the genus level for fungi across five sites. QM: Quercus mongolica; SW: Shrub wood; LG: Larix gmelini; PK: Pinus koraiensis; ZM: Zea mays.

At the family level, 17 groups with average relative abundances higher than $1 \%$ were obtained in QM, SW, LG, PK, and ZM, including Chaetomiaceae (14.96\%, $3.59 \%, \quad 1.23 \%, \quad 5.11 \%, \quad 6.05 \%)$, Suillaceae $(0.14 \%$, $23.63 \%, 3.33 \%, 0.06 \%, 0.00 \%)$, Cordycipitaceae $(5.89 \%$, $12.26 \%, 2.38 \%, 0.36 \%, 1.31 \%)$, Trichocomaceae $(1.91 \%$, $1.25 \%, 5.49 \%, 3.29 \%, 8.56 \%)$, Sebacinaceae $(2.56 \%$, $2.44 \%, 8.87 \%, 0.97 \%, 5.17 \%)$, Thelephoraceae $(1.68 \%$, $4.07 \%, \quad 6.53 \%, \quad 1.71 \%, \quad 0.55 \%)$, Geminibasidiaceae $(1.35 \%, \quad 0.02 \%, \quad 10.96 \%, \quad 0.62 \%, \quad 0.18 \%)$, Mortierellaceae $(2.45 \%, 2.12 \%, 2.40 \%, 1.11 \%, 5.01 \%)$, Atheliaceae $(0.07 \%, 6.43 \%, 4.00 \%, 0.04 \%, 0.08 \%)$, Dermateaceae $(0.29 \%, 0.02 \%, 8.95 \%, 0.04 \%, 0.58 \%)$, Nectriaceae $(1.70 \%, 0.44 \%, 0.22 \%, 1.26 \%, 5.19 \%)$, Hygrophoraceae $(0.15 \%, 0.16 \%, 0.01 \%, 7.31 \%, 0.06 \%)$, Myxotrichaceae $(0.56 \%, 1.32 \%, 3.90 \%, 0.23 \%, 0.68 \%)$, Herpotrichiellaceae $\quad(2.21 \%, \quad 0.58 \%, \quad 0.69 \%, \quad 2.16 \%$, $0.93 \%)$, Russulaceae $(0.27 \%, 0.02 \%, 2.26 \%, 0.78 \%$, $3.24 \%$, Lasiosphaeriaceae $(1.44 \%, \quad 0.74 \%, \quad 0.32 \%$, $0.67 \%, 2.72 \%)$, and Gnomoniaceae $(0.02 \%, 0.00 \%$, $0.00 \%, 5.20 \%, 0.10 \%$ ) (Supplement Fig. 2).

At the genus level, QM, SW, LG, PK, and ZM obtained 17 groups, with abundances higher than $1 \%$ (Fig. 4), including Suillus, Humicola, Sebacina, Simplicillium, Penicillium, Geminibasidium,

Table 4. Pearson correlations between the fungal community diversity and soil chemical characteristics.

\begin{tabular}{|c|c|c|c|c|c|c|c|}
\hline & $\mathrm{pH}$ & Total C & Total N & $\mathrm{C} / \mathrm{N}$ ratio & Available $\mathrm{N}$ & $\mathrm{NH}_{4}^{+}-\mathrm{N}^{2}$ & $\mathrm{NO}_{3}-\mathrm{N}$ \\
\hline Simpson index & 0.39 & -0.23 & -0.22 & -0.10 & -0.26 & $\mathbf{- 0 . 6 1}^{*}$ & -0.26 \\
\hline Chaol index & $\mathbf{0 . 5 6}$ & 0.12 & 0.12 & -0.02 & 0.09 & $\mathbf{- 0 . 5 8}^{*}$ & $\mathbf{- 0 . 5 8}^{*}$ \\
\hline ACE index & $\mathbf{0 . 5 4}$ & 0.11 & 0.12 & -0.04 & 0.09 & $\mathbf{- 0 . 5 5}^{*}$ & $\mathbf{- 0 . 5 7}^{*}$ \\
\hline Shannon index & $\mathbf{0 . 6 4}$ & 0.11 & 0.10 & 0.01 & 0.08 & $\mathbf{- 0 . 8 4}^{* *}$ & $\mathbf{- 0 . 5 3}^{*}$ \\
\hline
\end{tabular}

**correlation significant at 0.01 level (two-tailed); *correlation significant at 0.05 level (one-tailed). 

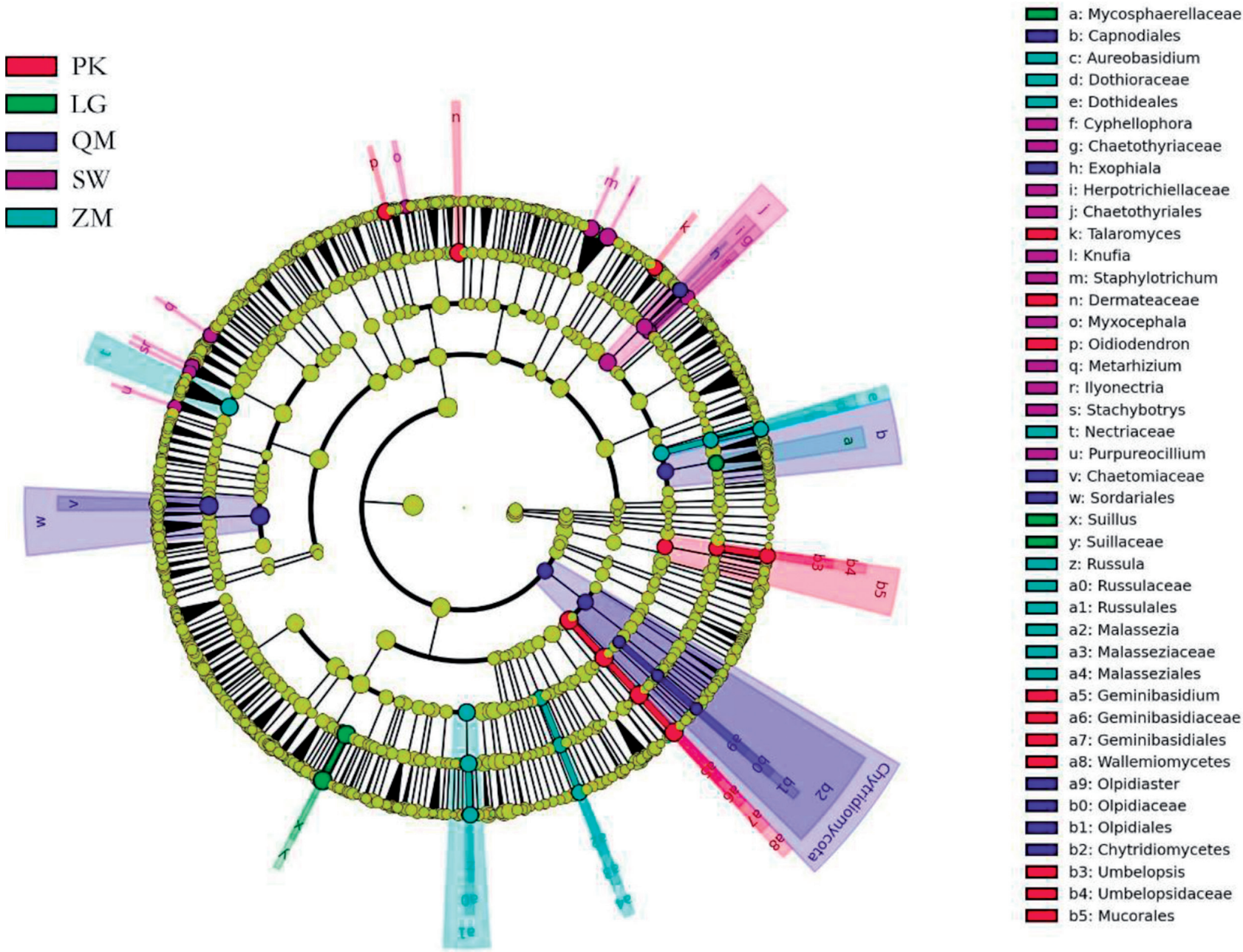

Fig. 5. The cladogram of soil fungal communities under five sites (LDA score =2.0). QM: Quercus mongolica; SW: Shrub wood; LG: Larix gmelini; PK: Pinus koraiensis; ZM: Zea mays. In the cladogram, the circles radiating represent fungal taxon from phylum to genus from the inside out, and the diameter of the circle is proportional to the relative abundance of each taxon. A taxon with significant difference is marked with the same color as the sampling site where the taxon is ranked the highest, and the branch area is correspondingly shaded. A taxon without a significant difference is marked in yellow.

Mortierella, Cryptococcus, Knufia, Hygrocybe, Piloderma, Chaetomium, Staphylotrichum, Russula, Tomentella, Bullera, and Gnomonia. There was a strong influence of different land-use types on the composition of the fungal communities. The genera Suillus and Simplicillium were more abundant in LG, whereas Geminibasidium and Cryptococcus were more abundant in PK. The relative abundance of Humicola was significantly higher in QM compared to the other sites, while Piloderma was only observed in LG, PK, and $\mathrm{ZM}$, and the genera Suillus was only present in QM, SW, LG, and PK. The genera Hygrocybe and Gnomonia were not found in PK (Fig. 4).

We used the linear discriminant analysis (LDA) effect size (LEfSe) to search for biomarkers with the soil fungal community phylogenetic tree in different classification levels under different sites with an LDA score of 2.0 (Fig. 5, Fig. S3). In total, 1 phylum, 2 classes, 10 orders, 12 families, and 18 genera showed significant differences under the different sites. At the phylum level, Chytridiomycota was enriched under QM. At the extremely significant difference with the LDA score of 4.5, the relative abundances of Sordariales, Chaetomiaceae, Suillus, Suillaceae, Wallemiomycetes, Geminibasidiales, Geminibasidium, Geminibasidiaceae and Dermateaceae differed significantly, which were found in PK, LG, and QM. The most significant differences were found for Sillus and Suillaceae, which showed the highest abundances in LG (Fig. S3).

A hierarchically clustered heatmap also illustrated that the relative abundances and distributions of soil fungi under different sites differed significantly. Based on these results, the five sites could be divided into two groups: one group included the QM and SW, and the other group included LG, PK, and ZM (Fig. 6). The NMDS plot based on unweighted unifrac distances showed that samples from LG and PK tended to be separated from the QM and SW, especially along NMDS1. Both analyses demonstrated that land use types had significant impacts on the soil fungal communities. 


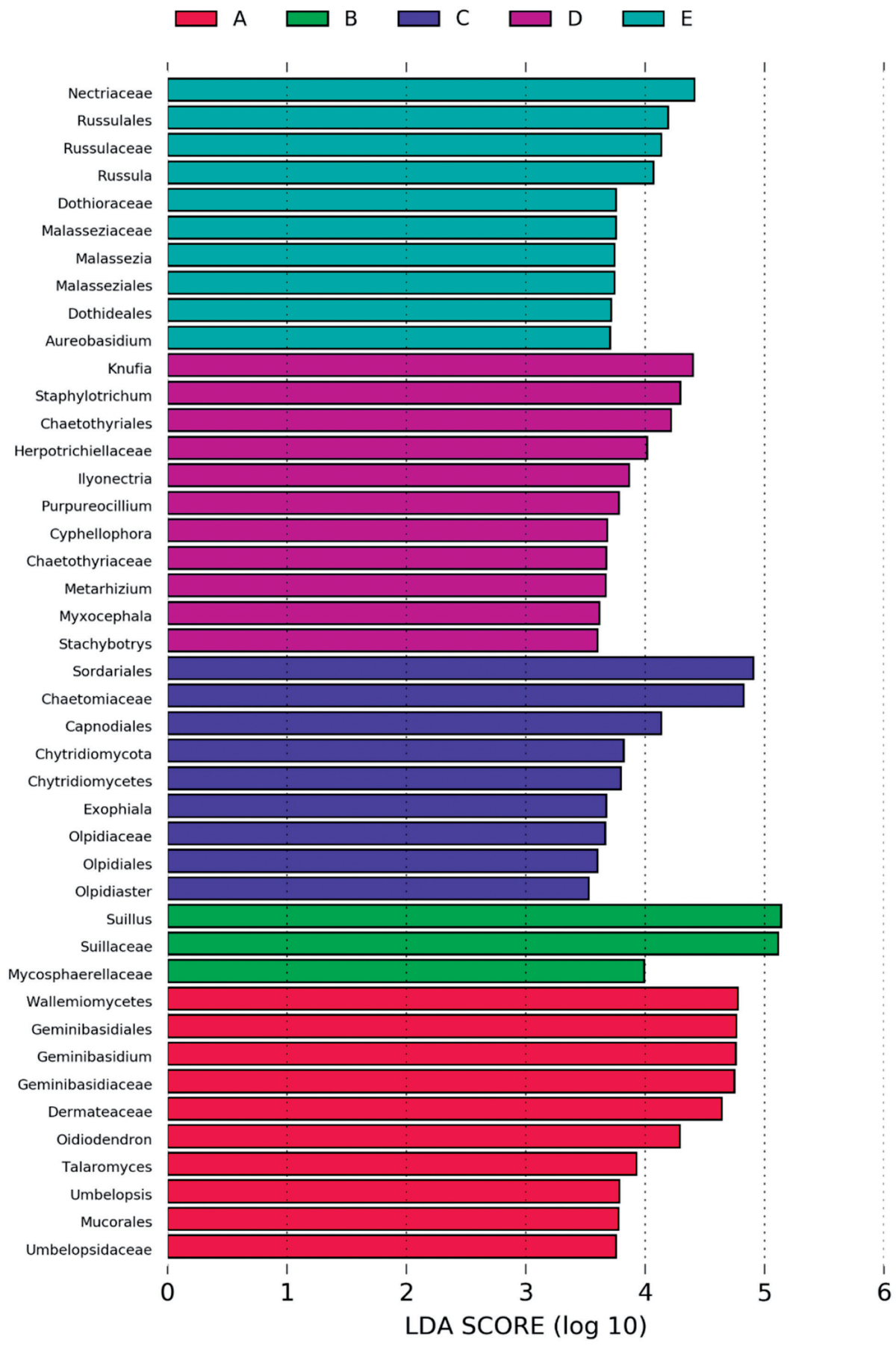

Fig. S3 The significantly changed fungal taxon under different sites. A: Pinus koraiensis (PK); B: Larix gmelini (LG); C: Quercus mongolica (QM); D: Shrub wood (SW); E: Zea mays (ZM).In the significantly changed fungal taxon under different land use patterns, the ordinate is a taxonomic unit with significant differences between groups, and the abscissa visualizes the logarithmic scores of the LDA difference analysis corresponding to the taxon, and sorts them according to the size of the scores to describe them as different. The size of the difference in the grouped sample. The longer the length, the more significant the difference between the taxon units, and the different color of the bar chart indicates the higher abundance sample group corresponding to the taxon.

\section{Relationship between Soil Fungal Communities and the Soil Properties}

We used CCA to analyze the variation in fungal community composition and the associated with soil characteristics. The CCA plots based on the dominant fungal phyla and genera were nearly identical
(Fig. 8). The overall composition of the dominant phyla or genera under different sites was significantly linked to the selected soil properties. At the phylum level, the eigenvalues of the first axis and the second axis were 0.947 and 0.053 , respectively (Fig. 8a), and the parameters $\mathrm{pH}(\mathrm{r}=0.79), \mathrm{NH}_{4}^{+}-\mathrm{N}$ content $(\mathrm{r}=-0.89)$, and $\mathrm{NO}_{3}{ }^{-} \mathrm{N}$ content $(\mathrm{r}=-0.75)$ had a more significant 


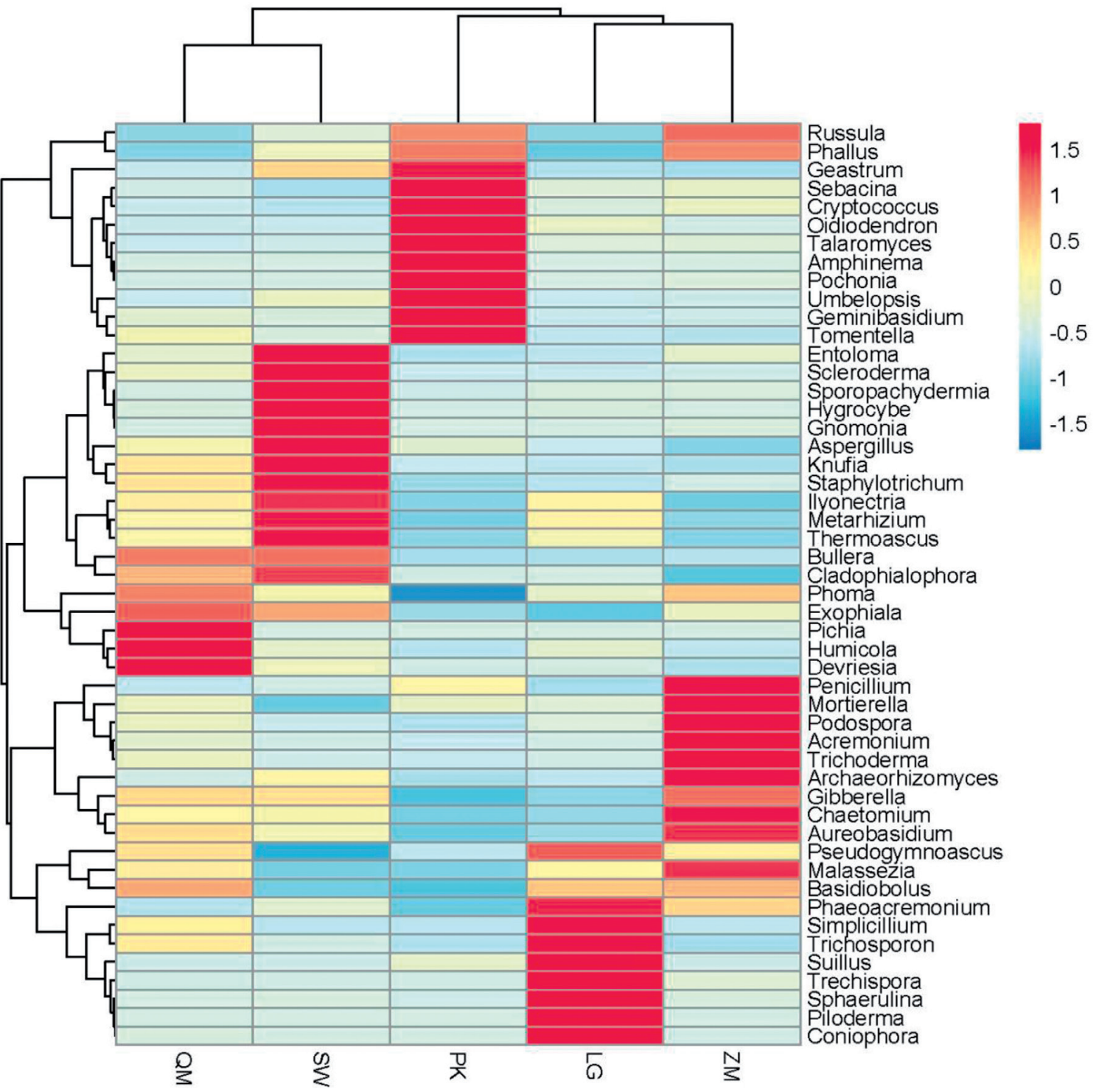

Fig. 6. Heatmap based on the relative abundances of the top 50 genera identified in the soil fungal communities. QM: Quercus mongolica; SW: Shrub wood; LG: Larix gmelini; PK: Pinus koraiensis; ZM: Zea mays.

realationship with Axis1. Pearson correlation analysis of dominant fungal groups and soil environmental factors showed that the relative abundance of Basidiomycota was negatively correlated with $\mathrm{pH}(\mathrm{r}=-0.55, P<0.05)$ and significantly positively correlated with soil $\mathrm{NH}_{4}^{+}-\mathrm{N}(\mathrm{r}=0.68, P<0.01)$. The relative abundance of
Ascomycota was negatively correlated with soil $\mathrm{NH}_{4}^{+}-\mathrm{N}$ ( $\mathrm{r}=-0.64, P<0.05)$ (Table 5).

At the genus level, the eigenvalue of Axis1 was 0.394 , and this axis had a greater realationship with soil $\mathrm{pH}(\mathrm{r}=-0.74)$ and $\mathrm{NO}_{3}^{-}-\mathrm{N}$ content $(\mathrm{r}=0.84)$, explaining $39.4 \%$ of the total microbial variance (Fig. 8b). Soil pH

Table 5. Correlation coefficients between dominant fungal groups and soil chemical characteristics.

\begin{tabular}{|c|c|c|c|c|c|c|c|}
\hline Fungal group & $\mathrm{pH}$ & Total C & Total N & $\mathrm{C} / \mathrm{N}$ ratio & Available $\mathrm{N}$ & $\mathrm{NH}_{4}^{+}-\mathrm{N}^{-}$ & $\mathrm{NO}_{3}^{-}-\mathrm{N}$ \\
\hline Phylum & -- & -- & -- & -- & -- & -- \\
\hline Ascomycota & 0.47 & 0.18 & 0.19 & -0.17 & 0.20 & $\mathbf{- 0 . 6 4}^{*}$ & -0.39 \\
\hline Basidiomycota & $\mathbf{- 0 . 5 5}$ & -0.10 & -0.09 & -0.04 & -0.11 & $\mathbf{0 . 6 8}^{* *}$ & 0.42 \\
\hline Zygomycota & -0.08 & -0.34 & -0.35 & 0.08 & -0.34 & -0.29 & 0.30 \\
\hline
\end{tabular}

** correlation significant at 0.01 level (two-tailed); * correlation significant at 0.05 level (two-tailed). 


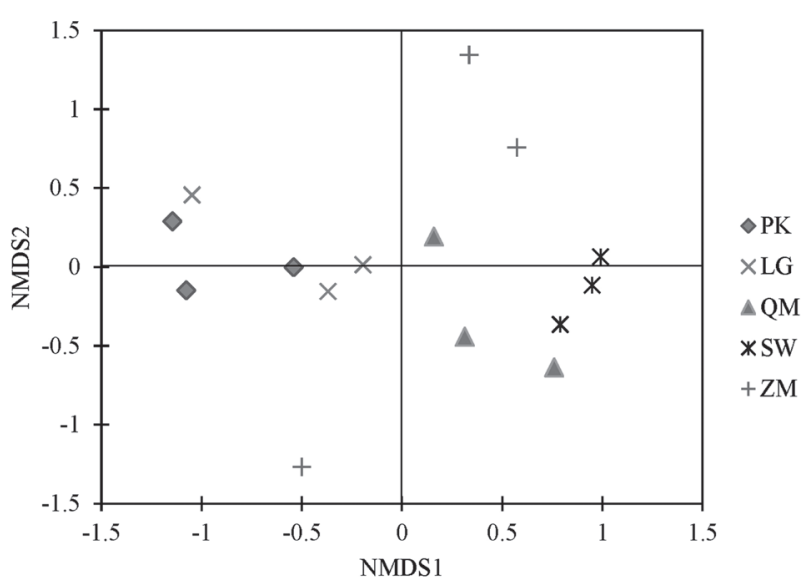

Fig. 7. Nonmetric multidimensional scaling (NMDS) plots under different sites. QM: Quercus mongolica; SW: Shrub wood; LG: Larix gmelini; PK: Pinus koraiensis; ZM: Zea mays.
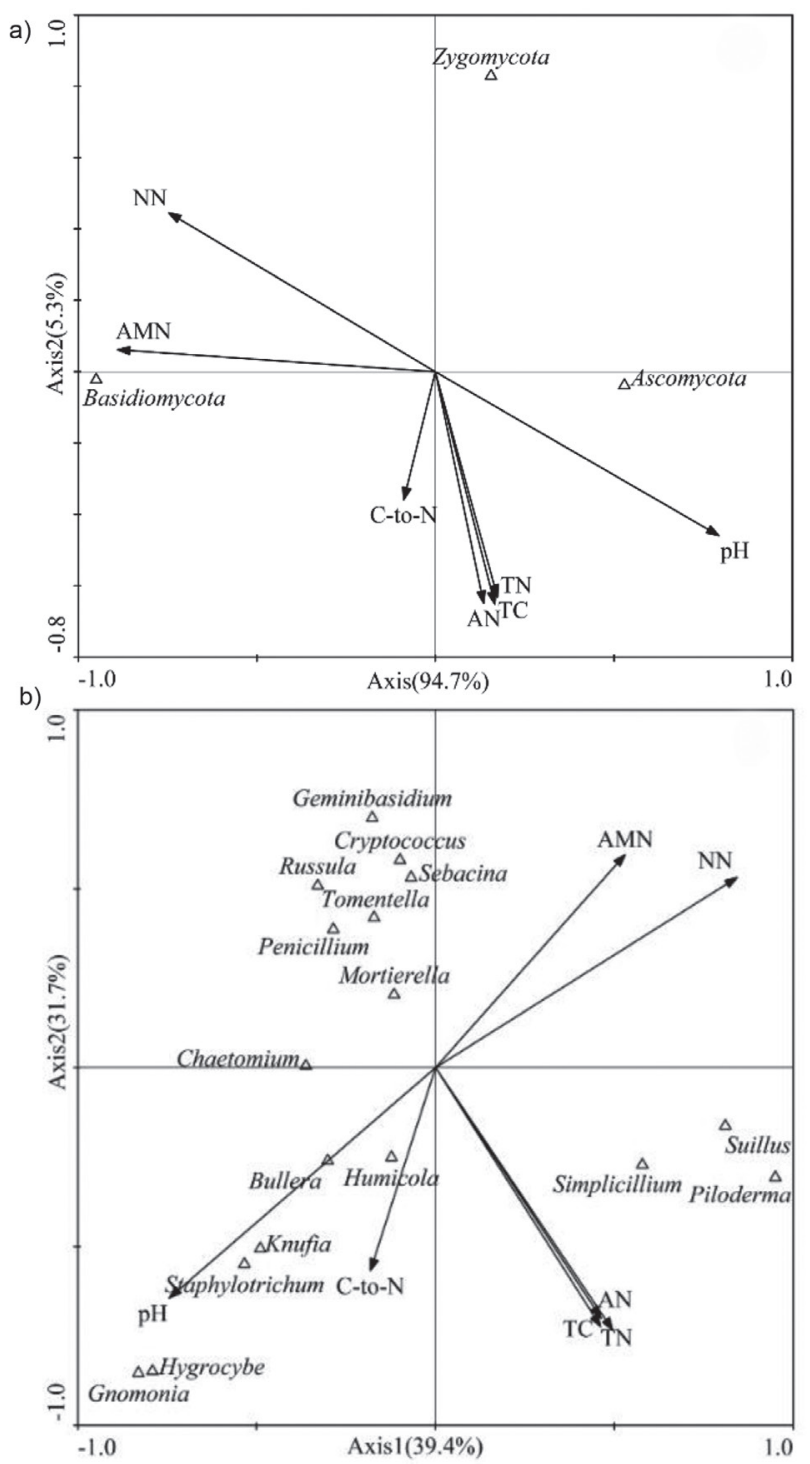

Fig. 8 Canonical correspondence analysis (CCA) used to evaluate the effect of soil factors on the fungal phylum (A) and fungal genus (B) structure. TC: total C; TN: total N, C/N: C/N ratio; $\mathrm{AN}$ : available $\mathrm{N}$; $\mathrm{NN}: \mathrm{NH}_{4}^{+}-\mathrm{N}$; $\mathrm{AMN}^{-} \mathrm{NO}^{3-}-\mathrm{N}$. $(\mathrm{r}=-0.64)$, total $\mathrm{C}(\mathrm{r}=-0.72)$, total $\mathrm{N}(\mathrm{r}=-0.70)$, and available $\mathrm{N}(\mathrm{r}=-0.73)$ were more closely related with Axis 2; the eigenvalue of Axis 2 was 0.317 . The two axes explained $71.1 \%$ of the total microbial variance and therefore reflected the influence of soil environmental factors on the soil fungal community structure.

\section{Variation of Predicted Metagenomes in Different Sites}

Using FUNGuild as a predictive exploratory tool, 8 functional groups of three trophic modes were detected in these datasets. The heatmap showed that the fungal functional guilds in different sites were divided into two groups: one group included QM, SW, and LG, and the other group included PK and ZM (Fig. 9). Five functional groups showed no significant differences among different QM, SW, LG, PK, and ZM, including pathogensaprotroph-symbiotroph, pathotroph, saprotroph, saprotroph-pathotroph-symbiotroph, and saprotrophsymbiotroph. Two functional groups, including pathotroph-saprotroph and pathotroph-symbiotroph showed the highest abundances in PK, significantly higher than in the other sites. Pathotroph-saprotrophsymbiotroph was significantly enriched in ZM (Fig. 10).

The functional guilds of 14 dominant fungal genera under different sites were presented in Table 6 , and saprotrophs were the most abundant guild in this area. The genera Suillus, Piloderma, Russula, and Tomentella belong to ectomycorrhizal fungi. The OTUs of ectomycorrhizal fungi varied among different sites, and the dominant ectomycorrhizal genus in our study was Suillus. The functional guild of Simplicillium is an animal pathogen and belongs to the pathotrophs, and no significant differences were observed among the different sites in terms of this genus. Gnomonia is a plant pathogen, and its OTUs were highest in ZM (Table 6).

\section{Discussion}

\section{Effects of Different Land-Use Types and Plant Species on Soil Chemical Characteristics}

Vegetation type and soil management of the land surface are determined by the different land-use types, which in turn affects soil physical and chemical characteristics such as nutrient levels and abiotic conditions [72-74]. In our research, soil chemical properties varied among the different sites (Table 2). And the total $\mathrm{C}$ and total $\mathrm{N}$ levels were lowest in the ZM, which was consistent with other researches [75]. Land-use change, in particular the conversion of primary forest to agricultural ecosystems, is regarded as one of the large sources of soil C [14], in some cases, total nitrogen losses [23-24]. There is no exception to this principle in China [76-78], including the eastern mountainous region of Liaoning Province. 


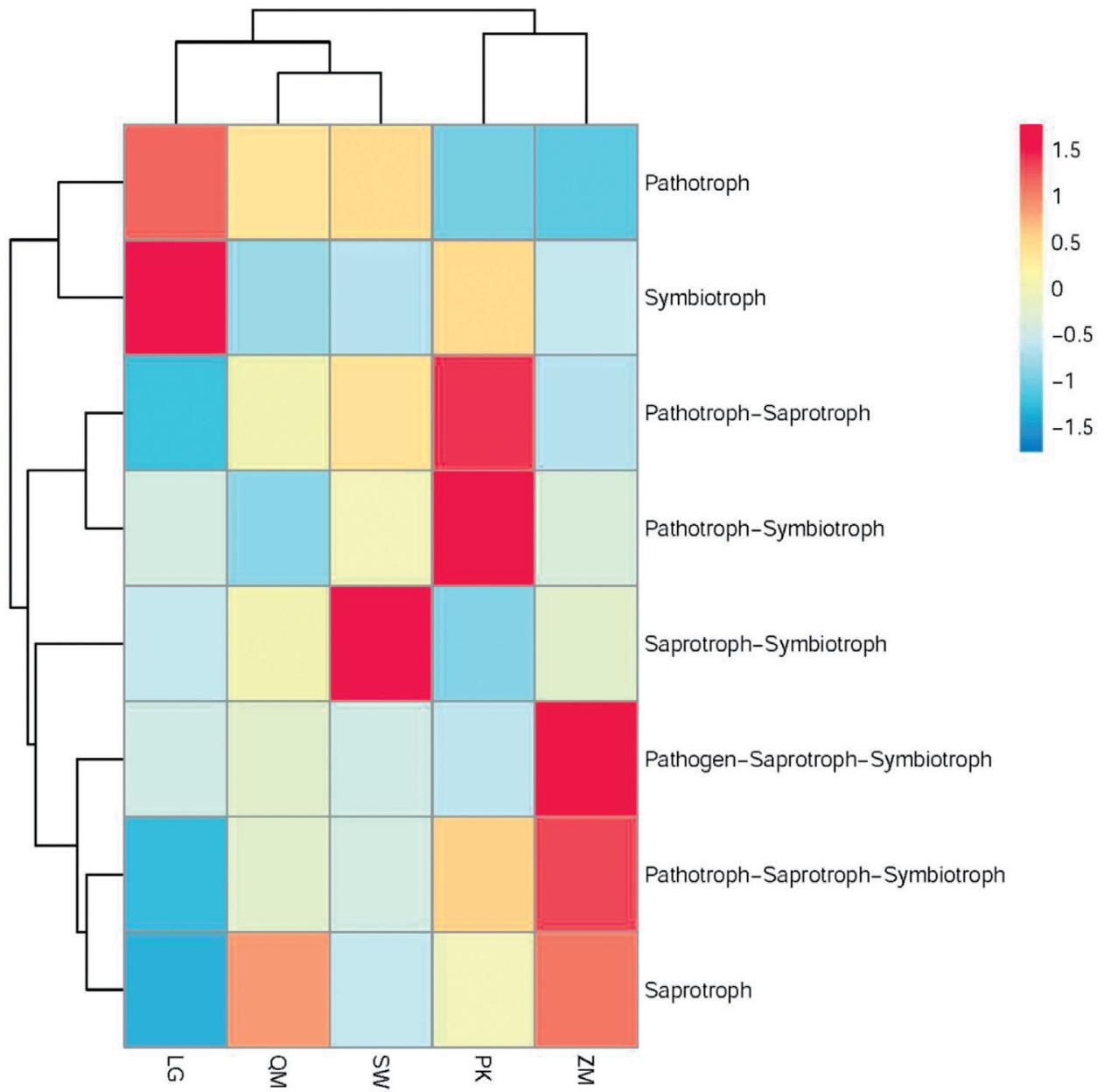

Fig. 9. Heatmap based on the relative abundances of the functional guilds. QM: Quercus mongolica; SW: Shrub wood; LG: Larix gmelini; PK: Pinus koraiensis; ZM: Zea mays.

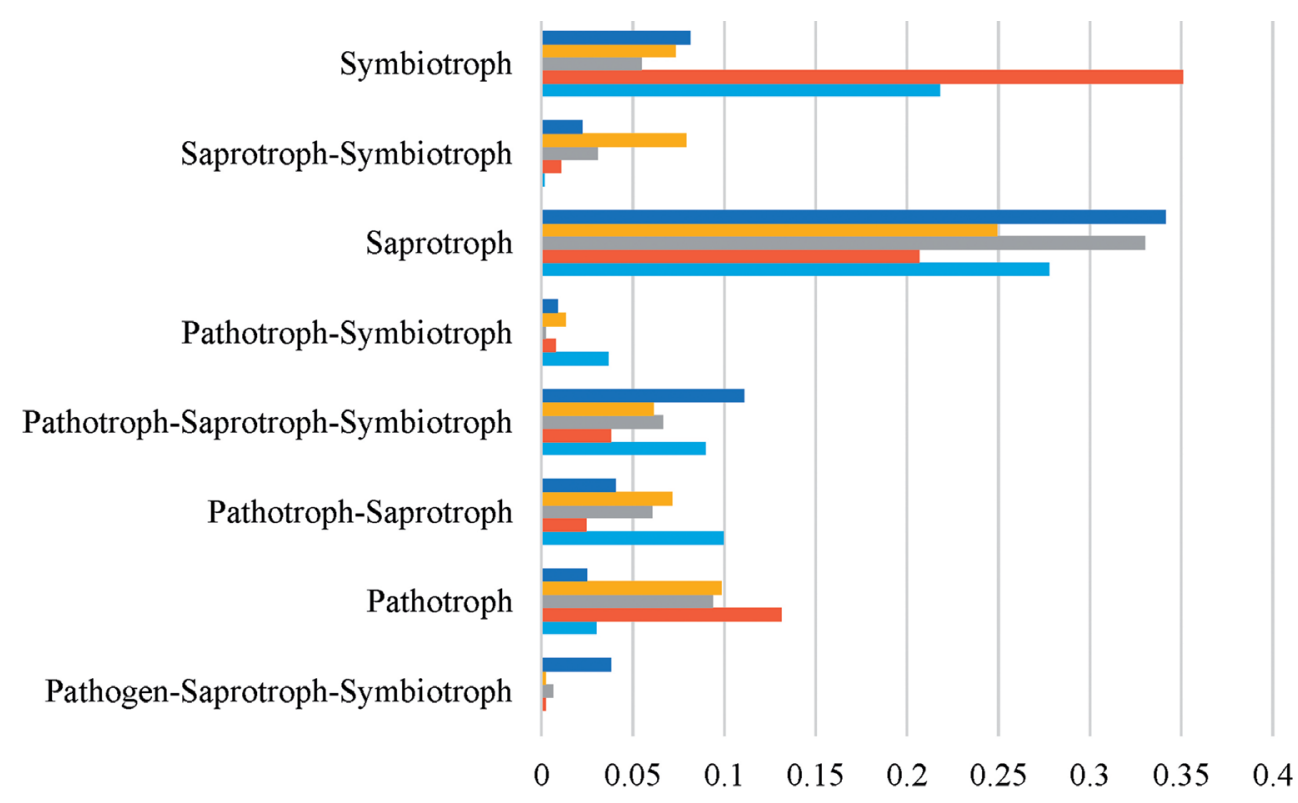

Relative abundance of metagenomes

$$
\square \mathrm{ZM} \backsim \mathrm{SW} \square \mathrm{QM} \backsim \mathrm{LG} \backsim \mathrm{PK}
$$

Fig. 10. Relative abundances of the different functional guilds under different sites. QM: Quercus mongolica; SW: Shrub wood; LG: Larix gmelini; PK: Pinus koraiensis; ZM: Zea mays. 
Table 6. The functional guilds of 14 dominant fungal genera under different sites.

\begin{tabular}{|c|c|c|c|c|c|c|c|}
\hline \multirow{2}{*}{ Genus } & \multirow{2}{*}{ Trophic Mode } & \multirow{2}{*}{ Functional guild } & \multicolumn{5}{|c|}{ Number of OTUs } \\
\hline & & & QM & SW & LG & PK & $\mathrm{ZM}$ \\
\hline Suillus & Symbiotroph & Ectomycorrhizal & 27 & 11 & 4460 & 627 & 0 \\
\hline Humicola & Saprotroph & Undefined Saprotroph-Wood Saprotroph & 2496 & 662 & 610 & 209 & 231 \\
\hline Sebacina & Symbiotroph & $\begin{array}{l}\text { Ectomycorrhizal-Orchid Mycorrhizal-Root } \\
\text { Associated Biotroph }\end{array}$ & 269 & 93 & 353 & 1671 & 472 \\
\hline Geminibasidium & Saprotroph & Undefined Saprotroph & 255 & 118 & 4 & 2066 & 33 \\
\hline Mortierella & Saprotroph & Undefined Saprotroph & 462 & 209 & 400 & 453 & 945 \\
\hline Simplicillium & Pathotroph & Animal Pathogen & 829 & 26 & 1930 & 13 & 60 \\
\hline Knufia & Pathotroph-Saprotroph & $\begin{array}{l}\text { Animal Pathogen-Plant Pathogen-Soil } \\
\text { Saprotroph-Undefined Saprotroph }\end{array}$ & 449 & 449 & 449 & 449 & 449 \\
\hline Piloderma & Symbiotroph & Ectomycorrhizal & 3 & 1212 & 0 & 0 & 1 \\
\hline Hygrocybe & Saprotroph-Symbiotroph & Undefined Saprotroph-Undefined Biotroph & 28 & 1375 & 28 & 0 & 11 \\
\hline Chaetomium & $\begin{array}{l}\text { Pathotroph-Saprotroph } \\
\text {-Symbiotroph }\end{array}$ & $\begin{array}{c}\text { Animal Pathogen-Dung Saprotroph } \\
\text {-Endophyte-Epiphyte-Plant Saprotroph- } \\
\text { Wood Saprotroph }\end{array}$ & 265 & 251 & 53 & 20 & 535 \\
\hline Staphylotrichum & Saprotroph & Undefined Saprotroph & 328 & 638 & 42 & 2 & 89 \\
\hline Russula & Symbiotroph & Ectomycorrhizal & 36 & 147 & 3 & 426 & 563 \\
\hline Tomentella & Symbiotroph & Ectomycorrhizal & 205 & 103 & 52 & 615 & 47 \\
\hline Gnomonia & Pathotroph & Plant Pathogen & 3 & 983 & 1 & 0 & 18 \\
\hline
\end{tabular}

QM: Quercus mongolica; SW: Shrub wood; LG: Larix gmelini; PK: Pinus koraiensis; ZM: Zea mays.

Deep tillage activities after the application of fertilizer to farmland frequently leads to the disruption of the soil structure, an increased surface area of the contact between SOM and soil microbes, the physical release of SOM previously trapped/bound, the breakdown of plant residue, and increased aeration, consequently accelerating the release of soil organic carbon into the atmosphere [79-81]. Moreover, in agricultural land, litter accumulation, consequently, nutrient return to the soil, are lower. Both of these processes would reduce the input of organic $\mathrm{C}$ into the soil environment and may also explain the reduction in soil total $\mathrm{C}$ and total $\mathrm{N}$, suggesting the loss of soil carbon and nitrogen in the process of transforming forests into farmland. It is found that QM owned higher levels of soil total C, total $\mathrm{N}$, and available $\mathrm{N}$ than $\mathrm{SW}, \mathrm{LG}, \mathrm{PK}$, demonstrating the potential positive effects of QM on soil nutrient conditions. Similarly, previous studies have reported that the concentration of soil organic carbon decreased after conversion of natural forests to Pinus plantations [82-84], which was similar to what was observed in our study. Inputs of carbon, nitrogen, and organic matter into soil are mainly due to the return of nutrients and biological nitrogen fixation in the litter [85]. Although the sites LG and PK were coniferous forests, the contents of soil total $\mathrm{C}$, total $\mathrm{N}$, and available $\mathrm{N}$ under LG land were significantly higher than those under PK land $(P<0.05)$ (Table 2). LG belongs to cold-temperate deciduous coniferous forests with a large amount of litter than PK, which is as a temperate evergreen coniferous forest with less litter [65], which in turn enormously established that land use types and plant species affect soil property significantly. The soil in this region had a $\mathrm{pH}$ value ranging from 5.54 to 6.29 , and the values were higher in QM and SW. Compared to $\mathrm{SW}$, the $\mathrm{ZM}$ land reduced soil $\mathrm{pH}$ (Table 2), which may be mainly due to the increase in soil $\mathrm{NO}_{3}^{-}-\mathrm{N}$ content after increasing nitrogen input leads to a decrease in soil $\mathrm{pH}$ value. In our study, the conservation of secondary forests to plantation forests resulted in increased $\mathrm{NH}_{4}^{+}-\mathrm{N}$ and $\mathrm{NO}_{3}^{-}-\mathrm{N}$ concentrations, which was in agreement with the findings of a study performed in Xishuangbanna [86]. These results illustrated that plantations (LG and PK) and SW did not improve soil conditions to the same degree as QM did, highlighting the potential positive effects of QM on soil nutrient conditions, and agriculture land use type could decrease the soil nutrients.

\section{Response of the Soil Fungal Community and Functions to Different Sites}

The fungal diversity index is an effective method to evaluate the diversity of different soil fungal communities. In our study, the Chaol index and ACE index in QM and SW were significantly higher than 
those in LG, PK, and ZM. With land use change from SW to ZM, the Chaol index, and ACE index decreased dramatically, while, the Shannon index and Simpson index increased (Table 3). Our results did not completely agree with a previous report that the conversion from tropical rainforest to dryland agriculture brought about no differences in Shannon index and a decline in Chaol index and Simpson index [58]. A previous study has suggested that long-term nitrogen application could reduce soil fungal diversity and fungal community composition [87]. And different nutrient levels result in differences in the microbial community structure and in functional diversity [88]. Fungi can live within wide $\mathrm{pH}$ and temperature ranges and are common in almost every environment [89]. In our study, $\mathrm{pH}$ was significantly positively related with the Chaol index, ACE index, and Shannon index (Table 4), which was in agreement with the previous research from Xishuangbanna Tropical Botanical, where soils with near-neutral $\mathrm{pH}$ had a higher fungal richness [58]. This might be explained by the application of high fertilizer doses to ZM, which decreased soil $\mathrm{pH}$ and weakened the diversity of the fungi [90]. In previous studies, long-term fertilizer application also adversely impacted microbe populations [91-92].

Similar to the fungal diversity, the fungal community structure varied among different land-use types and plant species. Land-use type plays a key role in modulating the soil fungal community structure [93-94], even at a small geographical scale. Some studies have reported that the composition and distribution of soil fungal communities were affected by the different plants because of the differences in rhizosphere secretions [95]. We observed a relative abundance of the dominant fungal phylum Ascomycota, followed by Basidiomycota and Zygomycota (Fig. 3), which was consistent with the findings of previous studies in tropical forests in Peruvian Amazonia and Panama [96-97]. In contrast, research in the Gutianshan National Nature Reserve has shown a dominance of Basidiomycota over Ascomycota and Zygomycota [98], while Curlevski et al. [99] have reported that Zygomycota was the dominant phylum. According to a previous study, Ascomycota and Basidiomycota can aerobically degrade cellulose, polyphenolic compounds, and other dissolved organic matter [100], and the preponderance of Ascomycota and Basidiomycota at the surface soil was consistent with this ability. The relative abundances of Ascomycota, Basidiomycota, and Zygomycota varied among the different sites. Ascomycota showed the highest relative abundance under QM (Fig. 3), which was negatively correlated with soil $\mathrm{NH}_{4}^{+}-\mathrm{N}$. Previous studies have shown that Ascomycota play a key role in decomposition processes [101], and the relative abundance of Ascomycota increases with increasing soil nitrogen levels [102]. Compositional shifts in fungal communities, with a decrease of Basidiomycota and an increase of Ascomycota in agricultural transformation systems in comparison to secondary forests, as observed in our study, have also been shown elsewhere [103-104]. However, compared to Ascomycota and Basidiomycota, the relative abundance of Zygomycota was considerably lower. Previous studies have illustrated that the Zygomycota physiology may be distinct from that of Ascomycota and Basidiomycota [105]. By producing thick-walled and resistant spores, Zygomycota can survive over long periods of dormancy [106]. Additionally, Zygomycota members cannot use cellulose and sucrose degradation products [107], although they can use $\mathrm{C}$ substrates of animal and fungal origin, such as fungal hyphae [108]. We believe that, in the carbon cycling, Zygomycota may play a key role, with a similar importance as Ascomycota and Basidiomycota.

The OTUs of the functional guilds of 14 dominant fungal genera differed under different land-use types. Ectomycorrhizal fungi represented the most abundant guild in the eastern mountainous region of Liaoning Province, and the dominant ectomycorrhizal genus in our study was the Suillus (Table 6). The lower OTUs number of Tomentella in the PK and ZM may be due to its nutritional requirements or lack of available arthropods and other animal vectors focusing on the dispersal of basidiospores [109]. In our study, after the conversion from SW to $\mathrm{ZM}$, the abundances of Mortierella, Humicola, Piloderma, Hygrocybe, Staphylotrichum, Russula, and Gnomonia changed significantly. Mortierella groups have been suggested to be saprobes in forest ecosystems [110]. Mortierella may be tracking changes in nutrients driven by vegetation turnover because of their potentially endophytic trophic lifestyle [111].

At the scale of the five different sites, we found large changes in fungal community composition, particularly between the secondary forest and the plantation forests plus agricultural land (Fig. 6), which was consistent with the results of a previous study [93]. The NMDS plot showed that samples from LG and PK tended to be separated from those of $\mathrm{QM}$ and $\mathrm{SW}$, especially along NMDS1 (Fig. 7). However, the fungal functional guilds in different land use types were divided into two groups, including QM, SW, plus LG, and PK plus ZM. Both analyses demonstrated that similar land use types usually have similar fungal communities [112], and significant difference were observed among different plant species under the same land use type. This is most likely because land-use change and plant species have led to drastic changes in plant biomass and litter inputs, severely affecting the soil fungal community composition [113-114].

\section{Different Land-Use Types and Plant Species Affect the Fungal Community through Influencing Soil Chemical Properties}

In this study, we provided, for the first time, insights into the contribution of land-use types, plant species and soil properties in shaping the composition of soil fungal communities in the eastern mountainous region of 
Liaoning Province. Differences in microbial community composition following land use change and plant species also have been attributed to differences in soil properties [115-116]. Previous studies have established that changes in land use types could lead to changes in soil $\mathrm{pH}$, soil moisture, and temperature [117-118], which in turn would inevitably affect microbial biomass and activity, as well as the microbial community structure [119]. The key role of soil properties in regulating the microbial community was clearly shown in this study. Fungal communities were correlated with soil chemical properties, such as soil $\mathrm{pH}, \mathrm{NH}_{4}^{+}-\mathrm{N}$ content, and soil $\mathrm{NO}_{3}^{-}-\mathrm{N}$ content (Fig. 8), and a previous study has indicated that the fungal community composition was correlated with $\mathrm{NO}_{3}^{-}-\mathrm{N}$, and soil $\mathrm{pH}$ [120]. Land use conversion-induced changes in the soil microbial community have also been related to soil $\mathrm{pH}$ and $\mathrm{NH}_{4}^{+}-\mathrm{N}$ content [121]. Basidiomycota was negatively correlated with $\mathrm{pH}$, which was significantly positively correlated with soil $\mathrm{NH}_{4}^{+}-\mathrm{N}$. In contrast to our findings, in a previous study, Basidiomycota was positively correlated with total $\mathrm{N}, \mathrm{C} / \mathrm{N}$, and $\mathrm{NO}_{3}^{-}-\mathrm{N}$ [122]. Soil $\mathrm{pH}$, soil $\mathrm{NH}_{4}^{+}-\mathrm{N}$ content, and soil $\mathrm{NO}_{3}^{-}-\mathrm{N}$ content were the main factors influencing the fungal community in our study area.

\section{Conclusions}

Forest plantations (LG and PK) did not improve soil conditions to the same degree as QM, and farmland (ZM) could decrease soil fertility compared to SW. Different land-use types, natural secondary forest (QM) conversion to plantation coniferous forest (LG, $\mathrm{PK}$ ), and shrub wood (SW) conversion to agriculture (ZM) strongly affected fungal community diversity and structure, and the fungal communities from LG, $\mathrm{PK}$, and ZM tended to be separated from those of QM and SW. When SW was changed into ZM, the Chaol index, and ACE index decreased dramatically, while, the Shannon index and Simpson index increased. And significant difference of soil characteristics and soil fungal communities were observed among different plant species under the same land use type. Land-use changes resulted in changes in the soil chemical properties, thereby controlling the composition of the soil fungal community. And soil $\mathrm{pH}$, soil $\mathrm{NH}_{4}^{+}-\mathrm{N}$ content, and soil $\mathrm{NO}_{3}^{-}-\mathrm{N}$ content were the main factors influencing the fungal community.

\section{Acknowledgment}

This research was financially supported by the National Science and Technology Support Program of China (2015BAD07B30103), the Sub-project of the National Key Research and Development Program (2017YFC050410501), the Special Fund for Forest Scientific Research in the Public Welfare (201304216), and Cfern and Beijing Techno Solutions Award Funds on Excellent Academic Achievements.

\section{Conflict of Interest}

The authors declare no conflict of interest.

\section{References}

1. KRASHEVSKA V., KLARNER B., WIDYASTUTI R., MARAUN M., SCHEU S. Impact of tropical lowland rainforest conversion into rubber and oil palm plantations on soil microbial communities. Biology and Fertility of Soils, 51, 697, 2015.

2. GEIST H.J., LAMBIN E.F. Proximate causes and underlying driving forces of tropical deforestation. Bioscience, 52, 143, 2002.

3. FEARNSIDE P. Deforestation in Brazilian Amazonia: history, rates and consequences. Conservation Biology, 19, 680, 2005.

4. PAULA F.S., RODRIGUES J.L., ZHOU J., MUELLER R.C., MIRZA B.S., BOHANNAN B.J.M., NÜSSLEIN K., DENG Y., TIEDJE J.M., PELLIZARI V. Land use change alters functional gene diversity, composition and abundance in Amazon forest soil microbial communities. Molecular Ecology, 23, 2988-2999, 2014.

5. PABST H., KÜHNEL A., KUZYAKOV, Y. Effect of land-use and elevation on microbial biomass and water extractable carbon in soils of Mt. Kilimanjaro ecosystems: a section of Agriculture, Ecosystems and Environment. Applied Soil Ecology, 67, 10, 2013.

6. THOMSON B.C., TISSERANT E., PLASSART P., UROZ S., GRIFFITHS R.I., HANNULA S.E., BUÉE M., MOUGEL C., RANJARD L., VAN VEEN J.A., MARTIN F.M., BAILEY M.J., LEMANCEAU P Soil conditions and land use intensification effects on soil microbial communities across a range of European field sites. Soil Biology and Biochemistry, 88, 403, 2015.

7. CAPUTO J., BEIER C.M., GROFFMAN P.M., BURNS D.A., BEALL F.D., HAZLETT P.W., YORKS T. Effects of harvesting forest biomass on water and climate regulation services: a synthesis of long-term ecosystem experiments in eastern North America. Ecosystems, 19, 271, 2016.

8. AYALA-OROZCO B., GAVITO M.E., MORA F., SIDDIQUE I., BALVANERA P., JARAMILLO V.J., AVALOS H.C., ROMERO-DUQUE L.P., MARTÍNEZMEYER E. Resilience of soil properties to land-use change in a tropical dry forest ecosystem. Land Degradation and Development, 29, 315, 2017.

9. DENG L., KIM D.G., PENG C., SHANGGUAN Z.P. Controls of soil and aggregate-associated organic carbon variations following natural vegetation restoration on the Loess Plateau in China. Land Degradation and Development, 29, 3974, 2018.

10. XIAO H.F., TIAN Y.H., ZHOU H.P., AI X.S., YANG X.D., SCHAEFER D. Intensive rubber cultivation degrades soil nematode communities in Xishuangbanna, southwest China. Soil Biology and Biochemistry, 76, 161, 2014.

11. MONTECCHIA M.S., TOSI M., SORIA M.A., VOGRIG J.A., SYDORENKO O., CORREA O.S. Pyrosequencing reveals changes in soil bacterial communities after 
conversion of Yungas forests to agriculture. PloS One, 10, e0119426, 2015.

12. TILMAN D., CASSMAN K.G., MATSON P.A., NAYLOR R., POLASKY S. Agricultural sustainability and intensive production practices. Nature (London), 418, 671, 2002.

13. ALLEN K., CORRE M.D., TJOA A., VELDKAMP E. Soil nitrogen-cycling responses to conversion of lowland forests to oil palm and rubber plantations in Sumatra, Indonesia. PloS One, 10, e 0133325, 2015.

14. VAN STRAATEN O., CORRE M.D., WOLF K., TCHIENKOUA M., CUELLAR E., MATTHEWS R.B., VELDKAMP E. Conversion of lowland tropical forests to tree cash crop plantations loses up to one-half of stored soil organic carbon. Proceedings of the National Academy of Sciences, 112, 9956, 2015.

15. BERENDSE F., RUIJVEN J.V., JONGEJANS E., KEESSTRA S. Loss of plant species diversity reduces soil erosion resistance. Ecosystems, 18, 881, 2015.

16. HASSLER E., CORRE M.D., TJOA A., DAMRIS M., UTAMI S.R., VELDKAMP E. Soil fertility controls soil-atmosphere carbon dioxide and methane fluxes in a tropical landscape converted from lowland forest to rubber and oil palm plantations. Biogeosciences, 12, 5831, 2015.

17. ALAVAISHA E., MANZONI S., LINDBORG R. Different agricultural practices affect soil carbon, nitrogen and phosphorous in Kilombero-Tanzania. Journal of Environmental Management, 234, 159, 2019.

18. HOLLAND T.C., BOWEN P.A., BOGDANOFF C.P, LOWERY D.T., SHAPOSHNIKOVA O., SMITH S., HART M. Evaluating the diversity of soil microbial communities in vineyards relative to adjacent native ecosystems. Applied Soil Ecology, 100, 91, 2016.

19. ACHARD F., BEUCHLE R., MAYAUX P., STIBIG H.J., BODART C., BRINK A., CARBONI S., DESCLÉE B., DONNAY F., EVA H.D., LUPI A., RA?I R., SELIGER R., SIMONETTI D. Determination of tropical deforestation rates and related carbon losses from 1990 to 2010. Global Change Biology, 20, 2540, 2014.

20. GASPARRI N.I., GRAU H.R. Deforestation and fragmentation of Chaco dry forest in NW Argentina (19722007). Forest Ecology Management, 258, 913, 2009.

21. VOLANTE J.N., ALCARAZSEGURA D., MOSCIARO M.J., VIGLIZZO E.F., PARUELO J.M. Ecosystem functional changes associated with land clearing in NW Argentina. Agriculture Ecosystems and Environment, 154, 12, 2012.

22. RAHMAN M.H., OKUBO A., SUGIYAMA S., MAYLANDC H.F. Physical, chemical and microbiological properties of an Andisol as related to land use and tillage practice. Soil and Tillage Research, 101, 10, 2008.

23. MURTY D., KIRSCHBAUM M.U.F., MCMURTRIE R.E., MCGILVRAY H. Does conversion of forest to agricultural land change soil carbon and nitrogen?. a review of the literature. Global Change Biology, 8, 105, 2010.

24. DON A., SCHUMACHER J., FREIBAUER A. Impact of tropical land-use change on soil organic carbon stocks-a meta-analysis. Global Change Biology, 17, 1658, 2015.

25. WALLENIUS K., RITA H., MIKKONEN A., LAPPI K., LINDSTRÖM K., HARTIKAINEN H., RAATELAND A., NIEMI R.M. Effects of land use on the level, variation and spatial structure of soil enzyme activities and bacterial communities. Soil Biology and Biochemistry, 43, 1464, 2011.

26. JOHNSON M.J., LEE K.Y., SCOW K.M. DNA fingerprinting reveals links among agricultural crops, soil properties, and the composition of soil microbial communities. Geoderma, 114, 279, 2003.

27. CHRISTIANL L., MICHAELS S., MARKA B., FIERER $\mathrm{N}$. The influence of soil properties on the structure of bacterial and fungal communities across land-use types. Soil Biology and Biochemistry, 40, 2407, 2008.

28. GUO X., CHEN H.Y.H., MENG M., BISWAS S.R., YE L., ZHANG J.Z. Effects of land use change on the composition of soil microbial communities in a managed subtropical forest. Forest Ecology Management, 373, 93, 2016.

29. MG V.D.H., BARDGETT R.D., VAN STRAALEN N.M. The unseen majority: soil microbes as drivers of plant diversity and productivity in terrestrial ecosystems. Ecology letters, 11, 296, 2010.

30. GANS J., WOLINSKY M., DUNBAR J. Response to comment by Bunge et al. on "Computational improvements reveal great bacterial diversity and high metal toxicity in soil". Science, 313, 918, 2006.

31. XU H.J., WANG X.H., LI H., YAO H.Y., SU J.Q., ZHU Y.G. Biochar impacts soil microbial community composition and nitrogen cycling in an acidic soil planted with rape. Environmental Science and Technology, 48, 9391, 2014

32. LIU X., ZHANG B., ZHAO W. Comparative effects of sulfuric and nitric acid rain on litter decomposition and soil microbial community in subtropical plantation of Yangtze River Delta region. Science of the Total Environment, 601602, 669, 2017.

33. LIN Y.T., WHITMAN W.B., COLEMAN D.C., JIEN S.H., CHUI C.Y. Cedar and bamboo plantations alter structure and diversity of the soil bacterial community from a hardwood forest in subtropical mountain. Applied Soil Ecology, 112, 28, 2017.

34. ZHANG Y., DU B.H., JIN Z.G., LI Z.H., SONG H.N., DING Y.Q. Analysis of bacterial communities in rhizosphere soil of healthy and diseased cotton (Gossypium, sp.) at different plant growth stages. Plant and Soil, 339, 447, 2011.

35. MCCANN K.S. The diversity-stability debate. Nature, 405, 228, 2000.

36. DELGADO-BAQUERIZO M., REICH P.B., KHACHANE A.N., CAMPBELL C.D., THOMAS N., FREITAG T.E., AL-SOUD W.A., SØRENSEN S., BARDGETT R.D., SINGH B.K. It is elemental: soil nutrient stoichiometry drives bacterial diversity. Environmental Microbiology, 19, 1176, 2016.

37. AGUILERA P., MARÍN C., OEHL F., GODOY R., BORIE F., CORNEJO P. Selection of aluminum tolerant cereal genotypes strongly influences the arbuscular mycorrhizal fungal communities in an acidic Andosol. Agriculture, Ecosystems and Environment, 246, 86, 2017.

38. CORNEJO P., MEIER S., GARCÍA S., FERROL N., DURÁN P., BORIE F., SEGUEL A. Contribution of inoculation with arbuscular mycorrhizal fungi to the bioremediation of a copper contaminated soil using Oenothera picensis. Journal of soil science and plant nutrition, 17, 14, 2017.

39. SUN J.M., IRZYKOWSKI W., JEDRYCZKA M., HAN F.X. Analysis of the genetic structure of Sclerotinia sclerotiorum (Lib.) de Bary populationsfrom different regions and host plants by andom Amplified PolymorphicDNA markers. Journal of Integrative Plant Biology, 47, 385, 2005.

40. BARBI F., PRUDENT E., VALLON L., BUÉE M., DUBOST A., LAGOUT A., MARMEISSE R., FRAISSINET-TACHET L., LUIS P. Tree species select 
diverse soil fungal communities expressing different sets of lignocellulolytic enzyme-encoding genes. Soil Biology and Biochemistry, 100, 149, 2016.

41. LAUBER C.L., STRICKLAND M.S., BRADFORD M.A., NOAH F. The influence of soil properties on the structure of bacterial and fungal communities across land-use types. Soil Biology and Biochemistry, 40, 2407, 2008.

42. UNGER I.M., GOYNE K.W., KREMER R.J. Microbial community diversity in agroforestry and grass vegetative filter strips. Agroforestry Systems, 87, 395, 2013.

43. LIENHARD P., TERRAT S., MATHIEU O., LEVÊQUE J., PRÉVOST-BOURÉ N.C., NOWAK V., RÉGNIER T., FAIVRE C., SAYPHOUMMIE S., PANYASIRI K., TIVET F., RANJARD L., MARON P.A.Soil microbial diversity and $\mathrm{C}$ turnover modified by tillage and cropping in Laos tropical grassland. Environmental Chemistry Letters, 11, 391, 2013.

44. BOSSIO D.A., FLECK J.A., SCOW K.M., FUJIID R. Alteration of soil microbial communities and water quality in restored wetlands. Soil Biology and Biochemistry, 38, 1223, 2006.

45. BARDGETT R.D., FREEMAN C., OSTLE N.J. Microbial contributions to climate change through carbon cycle feedbacks. The ISME journal, 2, 805, 2008.

46. BRACKIN R., ROBINSON N., LAKSHMANAN P., SCHMIDT S. Microbial function in adjacent subtropical forest and agricultural soil. Soil Biology and Biochemistry, 57, 68, 2013

47. BRINKMANN N., SCHNEIDER D., SAHNER J., BALLAUFF J., EDY N., BARUS H., IRAWAN B., BUDI S.W., QAIM M., DANIEL R., POLLE, A. Intensive tropical land use massively shifts soil fungal communities. Scientific reports, 9, 3403, 2019.

48. KOOCH Y., TARIGHAT F.S., HOSSEINI S.M. Tree species effects on soil chemical, biochemical and biological features in mixed Caspian lowland forests. Trees, 31, 1, 2016.

49. WANG J., REN C., CHENG H., ZOU Y., BUGHIO M.A., LI Q. Conversion of rainforest into agroforestry and monoculture plantation in China: consequences for soil phosphorus forms and microbial community. Science of the Total Environment, 595, 769, 2017.

50. CHASE P., SINGH O.P. Soil nutrients and fertility in three traditional land use systems of Khonoma, Nagaland, India. Resources and Environment, 4, 181, 2014.

51. TOSI M., CORREA O.S., SORIA M.A., VOGRIG J.A., SYDORENKO O., MONTECCHIA M.S. Land-use change affects the functionality of soil microbial communities: A chronosequence approach in the Argentinian Yungas. Applied Soil Ecology, 108, 118, 2016.

52. HUYGENS D., ROOBROECK D., COSYN L., SALAZAR F., GODOY R., NOECKX P. Microbial nitrogen dynamics in south central Chilean agricultural and forest ecosystems located on an Andisol. Nutrient Cycling in Agroecosystems, 89, 175, 2011.

53. HUI L., YE D.D., WANG X.G., SETTLES M.L., WANG J., HAO Z.Q., ZHOU L.S., DONG P., JIANG Y., MA Z.S. Soil bacterial communities of different natural forest types in Northeast China. Plant and Soil, 383, 203, 2014.

54. XIAO L., LIU G.B., XUE S. Effects of vegetational type and soil depth on soil microbial communities on the Loess Plateau of China. Archives of Agronomy and Soil Science, 62, 1665, 2016.

55. RODRIGUES J.L.M., PELLIZARI V.H., MUELLER R., BAEK K., JESUS EDA C., PAULA F.S., NÜSSLEIN K. Conversion of the Amazon rainforest to agriculture results in biotic homogenization of soil bacterial communities. Proceedings of the National Academy of Sciences of the United States of America, 110, 988, 2013.

56. MENDES L.W., DE LIMA BROSSI M.J., KURAMAE E.E., TSAI S.M. Land-use system shapes soil bacterial communities in Southeastern Amazon region. Applied Soil Ecology, 95, 151, 2015.

57. LAN G., LI Y.W., WU Z.X., XIE G. Soil bacterial diversity impacted by conversion of secondary forest to rubber or Eucalyptus plantations: A case study of Hainan Island, South China. Forest Science, 63, 87, 2017.

58. CAI Z.Q., ZHANG Y.H., YANG C., WANG S. Land-use type strongly shapes community composition, but not always diversity of soil microbes in tropical China. Catena, 165, 369, 2018.

59. ENG D.C. Soil taxonomy; a basic system of soil classification for making and interpreting soil surveys(By) soil survey staff. Geofisica Internacional, 99, 270, 1975.

60. WU S.J., DENG J.J., YIN Y., QIN S.J., ZHU W.X., ZHOU Y.B., WANG B., RUAN Y.H., JIN L. Bacterial Community Changes Associated with Land Use Type in the Forest Montane Region of Northeast China. Forests, 11 (1), 40, 2019.

61. REN C.J., ZHAO F.Z., KANG D., YANG G.H., HAN X.H., TONG X.G., YONGZHONG F., REN G.X. Linkages of C: N: P stoichiometry and bacterial community in soil following afforestation of former farmland. Forest Ecology Management, 376, 59, 2016.

62. SCHRUMPF M., SCHULZE E.D., KAISER K., SCHUMACHER J. How accurately can soil organic carbon stocks and stock changes be quantified by soil inventories?. Biogeosciences, 8, 1193, 2011.

63. BAO S.D. Soil and Agricultural Chemistry Analysis. Beijing: China Agriculture Press, 2000.

64. DENG J.J., YIN Y., LUO J.Y., ZHU W.X., ZHOU Y.B. Different revegetation types alter soil physical-chemical characteristics and fungal community in the Baishilazi Nature Reserve. PeerJ, 6, e6251, 2019.

65. DENG J.J., YIN Y., ZHU W.X., ZHOU Y.B. Variations in soil bacterial community diversity and structures among different revegetation types in the Baishilazi Nature Reserve. Frontiers in Microbiology, 9, 2874, 2018.

66. CAPORASO J.G., KUCZYNSKI J., STOMBAUGH J., BITTINGER K., BUSHMAN F.D., COSTELLO E.K., FIERER N., PEÑA A.G., GOODRICH J.,GORDON J.I., HUTTLEY G.A., KELLEY S.T., KNIGHTS D., KOENIG J.E., LEY R., LOZUPONE C., MCDONALD D., MUEGGE B.D., PIRRUNG M., REEDER J., SEVINSKY J.R., TURNBAUGH P.J., WALTERS W.A., WIDMANN J.J., YATSUNENKO T., ZANEVELD J., KNIGHT R. QIIME allows analysis of highthroughput community sequencing data. Nature Methods, 7, 335, 2010.

67. ZHONG Y., YAN W., SHANGGUAN Z. Impact of longterm $\mathrm{N}$ additions upon coupling between soil microbial community structure and activity, and nutrient-use efficiencies. Soil Biology and Biochemistry, 91, 151, 2015.

68. MAGOČ T., SALZBERG S.L. FLASH: fast length adjustment of short reads to improve genome assemblies. Bioinformatics, 27, 2957, 2011.

69. EDGAR R.C. Search and clustering orders of magnitude faster than BLAST. Bioinformatics, 26, 2460, 2010.

70. BOKULICH N.A., SUBRAMANIAN S., FAITH J.J., GEVERS D., GORDON J.I., KNIGHT R., MILLS D.A., CAPORASO J.G. Quality-filtering vastly improves 
diversity estimates from Illumina amplicon sequencing. Nature Methods, 10, 57, 2013.

71. NGUYEN N.H., SONG Z., BATES S.T., BRANCO S., TEDERSOO L., MENKE J., SCHILLING J., KENNEDY P. FUNGuild: an open annotation tool for parsing fungal community datasets by ecological guild. Fungal Ecology, 20, 241, 2016.

72. OBERSON A., FRIESEN D.K., RAO I.M., BÜHLER S., FROSSARD E. Phosphorus Transformations in an Oxisol under contrasting land-use systems: The role of the soil microbial biomass. Plant and Soil, 237, 197, 2001.

73. BATLLEAGUILAR J., BROVELLI A., PORPORATO A., BARRY D.A. Modelling soil carbon and nitrogen cycles during land use change. A review. Agronomy for Sustainable Development, 31, 251, 2011.

74. ALELE P.O., SHEIL D., SURGETGROBA Y., SHI L., CANNON C.H. How does conversion of natural tropical rainforest ecosystems affect soil bacterial and fungal communities in the Nile river watershed of Uganda?. PloS One, 9, e104818, 2014.

75. ZHAO W.Z., XIAO H.L., LIU Z.M., LI J. Soil degradation and restoration as affected by land use change in the semiarid Bashang area, northern China. Catena, 59, 173, 2005.

76. XIE Z.B., ZHU J.G., LIU G., CADISCH G., HASEGAWA T., CHEN C.M., SUN H.F, TANG H.Y., ZENG Q. Soil organic carbon stocks in China and changes from 1980s to 2000s. Global Change Biology, 13, 1989, 2010.

77. WU H., GUO Z., PENG C. Land use induced changes of organic carbon storage in soils of China. Global Change Biology, 9, 305, 2010.

78. XU M., LI X., CAI X., LI X., CHRISTIE P., ZHANG J. Land use alters arbuscular mycorrhizal fungal communities and their potential role in carbon sequestration on the Tibetan Plateau. Scientific Reports, 7, 3067, 2017.

79. GOVAERTS B., MEZZALAMA M., UNNO Y., SAYRE K.D., LUNA-GUIDO M., VANHERCK K., VANHERCK K., DENDOOVEN L., DECKERS J. Influence of tillage, residue management, and crop rotation on soil microbial biomass and catabolic diversity. Applied soil ecology, 37, $18,2007$.

80. USSIRI D.A.N., LAL R. Long-term tillage effects on soil carbon storage and carbon dioxide emissions in continuous corn cropping system from an alfisol in Ohio. Soil and Tillage Research, 104, 39, 2009.

81. KRAVCHENKO A.N., WANG A.N.W., SMUCKE A.J.M., RIVERS M.L. Long-term differences in tillage and land use affect intra-aggregate pore heterogeneity. Soil Science Society of America Journal, 75, 1658, 2011.

82. LEWIS T., SMITH T.E., HOGG B., SWIFT S., VERSTRATEN L., BRYANT P., WEHR B.J., TINDALE N., MENZIES N.W., DALAL R.C. Conversion of subtropical native vegetation to introduced conifer forest: Impacts on below-ground and above-ground carbon pools. Forest Ecology and Management, 370, 65, 2016.

83. FANG X.H., ZHANG J.C., MENG M.J., GUO X.P., WU Y.W., LIU X., ZHAO K.L., DING L.Z., SHAO Y.F., FU W.J. Forest-type shift and subsequent intensive management affected soil organic carbon and microbial community in southeastern China. European Journal of Forest Research, 136, 689, 2017.

84. LIN Z.W., LI Y.F., TANG C.X., LUO Y., FU W.J., CAI X.Q., LI Y.C., YUE T., JIANG P.K., HU S.D., CHANG S.X. Converting natural evergreen broadleaf forests to intensively managed moso bamboo plantations affects the pool size and stability of soil organic carbon and enzyme activities. Biology and Fertility of Soils, 54, 1, 2018.

85. XIONG H.F., WANG Y.H. Spatial variability of soil nutrients in wetland of Liangzi Lake. Plant Nutrition and Fertilizer Science, 11, 584, 2005.

86. LI H., MA Y., LIU W., LIU W. Soil Changes Induced by Rubber and Tea Plantation Establishment: Comparison with Tropical Rain Forest Soil in Xishuangbanna, SW China. Environmental Management, 50, 837, 2012.

87. ZHOU J., JIANG X., ZHOU B.K., ZHAO B.S., MA M.C., GUAN D.W., LI J., CHEN S.F., CAO F.M., SHEN D.L., QIN J. Thirty four years of nitrogen fertilization decreases fungal diversity and alters fungal community composition in black soil in northeast China. Soil Biology and Biochemistry, 95, 135, 2016.

88. SARATHCHANDRA S.U., GHANI A., YEATES G.W., BURCH G., COX N.R. Effect of nitrogen and phosphate fertilisers on microbial and nematode diversity in pasture soils. Soil Biology and Biochemistry, 33, 953, 2001.

89. FRĄC M., JEZIERSKA-TYS S., YAGUCHI T. Chapter Five-occurrence, detection, and molecular and metabolic characterization of heat-resistant fungi in soils and plants and their risk to human health. Advances in Agronomy. Academic Press, 132, 161, 2015.

90. SPOHN M., PÖTSCH E.M., EICHORST S.A., WOEBKEN D., WANEK W., RTCHTER A. Soil microbial carbon use efficiency and biomass turnover in a long-term fertilization experiment in a temperate grassland. Soil Biology and Biochemistry, 97, 168, 2016.

91. LIANG B., YANG X., HE X., ZHOU J. Effects of 17-year fertilization on soil microbial biomass $\mathrm{C}$ and $\mathrm{N}$ and soluble organic $\mathrm{C}$ and $\mathrm{N}$ in loessial soil during maize growth. Biology and Fertility of Soils, 47, 121, 2011.

92. SUI Y.Y., JIAO X.G., LIU X.B., ZHANG X.Y., DING G.W. Response of soil microbial biomass and enzyme activity to soil fertilization in an eroded farmland of Chinese Mollisols. Communications in Soil Science and Plant Analysis, 44, 2809, 2013.

93. LECKIE S.E., PRESCOTT C.E., GRAYSTON S.J., NEUFELD J.D., MOHN W.W. Characterization of humus microbial communities in adjacent forest types that differ in nitrogen availability. Microbial Ecology, 48, 29, 2004.

94. KASEL S., BENNETT L.T., TIBBITS J. Land use influences soil fungal community composition across central Victoria, south-eastern Australia. Soil Biology and Biochemistry, 40, 1724, 2008.

95. NAYYAR A., HAMEL C., LAFOND G., GOSSEN B.D., HANSON K., GERMIDA J. Soil microbial quality associated with yield reduction in continuous-pea. Applied Soil Ecology, 43, 115, 2009.

96. MCGUIRE K.L., FIERER N., BATEMAN C., TRESEDER K.K., TURNER B.L. Fungal community composition in neotropical rain forests: the influence of tree diversity and precipitation. Microbial Ecology, 63, 804, 2012.

97. PEAY K.G., BARALOTO C., FINE P.V.A. Strong coupling of plant and fungal community structure across western Amazonian rainforests. ISME Journal: Multidisciplinary Journal of Microbial Ecology, 7, 1852, 2013.

98. WU Y.T., WUBET T., TROGISCH S., BOTH S., SCHOLTEN T., BRUELHEIDE H., BUSCOT F. Forest age and plant species composition determine the soil fungal community composition in a Chinese subtropical forest. PloS One, 8, e66829, 2013.

99. CURLEVSKI N.J.A., XU Z., ANDERSON I.C., ANDERSON I.C., CAIRNEY J.W.G. Soil fungal communities differ in native mixed forest and adjacent 
Araucaria cunninghamii, plantations in subtropical Australia. Journal of soils and sediments, 10, 1278, 2010.

100. LYND L.R., WEIMER P.J., VAN-ZYL W.H., PRETORIUS I.S. Microbial cellulose utilization: fundamentals and biotechnology. Microbiology and Molecular Biology Reviews, 66, 506, 2002.

101. MA A., ZHUANG X., WU J., CUI M., LV D., LIU C., ZHUANG G. Ascomycota members dominate fungal communities during straw residue decomposition in arable soil. PloS One, 8, e66146, 2013.

102. PAUNGFOOLONHIENNE C., YUN K.Y., KASINADHUNI N.R.P., LONHIENNE T.G., ROBINSON N., HUGENHOLTZ P., RAGAN M.A., SCHMIDT S. Nitrogen fertilizer dose alters fungal communities in sugarcane soil and rhizosphere. Science Report, 5, 8678, 2015.

103. MCGUIRE K.L., D'ANGELO H., BREARLEY F.Q., GEDALLOVICH S.M., BABAR N., YANG N., GILLIKIN C.M., GRADOVILLE M.R., BATEMAN C.,TURNER B.L., MANSOR P., LEFF J.W., FIERER N. Responses of soil fungi to logging and oil palm agriculture in Southeast Asian tropical forests. Microbial Ecology, 69, 733, 2015.

104. KERFAHI D., TRIPATHI B.M., DONG K., GO R., ADAMS J.M. Rainforest conversion to rubber plantation may not result in lower soil diversity of bacteria, fungi, and nematodes. Microbial Ecology, 72, 359, 2016.

105. ZHANG Z.Q., ZHOU X., TIAN L., MA L., LUO S.S., ZHANG J.F., LI X.J., TIAN C.J. Fungal communities in ancient peatlands developed from different periods in the Sanjiang Plain, China. PloS One, 12, e0187575, 2017.

106. LIN X., GREEN S., TFAILY M.M., PRAKASH O., KONSTANTINIDIS K.T., CORBETT J.E., CHANTON J.P., COOPER W.T., KOSTKA J.E. Microbial community structure and activity linked to contrasting biogeochemical gradients in bog and fen environments of the Glacial Lake Agassiz peatland. Applied and Environmental Microbiology, 78, 7023, 2012.

107. KIM Y.J., ZHAO Y., OH K.T., NGUYEN V.N., PARK R.D. Enzymatic deacetylation of chitin by extracellular chitin deacetylase from a newly screened Mortierella sp. DY-52. Journal of Microbiology and Biotechnology, 18, 759, 2008.

108. BOER W.D., GERARDS S., GUNNEWIEK P.J.A.K., MODDERMAN R. Response of the chitinolytic microbial community to chitin amendments of dune soils. Biology and Fertility of Soils, 29, 170, 1999.

109. LILLESKOV E.A., BRUNS T.D. Spore dispersal of a resupinate ectomycorrhizal fungus, Tomentella sublilacina, via soil food webs. Mycologia, 97, 762, 2005.

110. HEITEFUSS R. Pictorial atlas of soil and seed fungi, morphologies of cultured fungi and key to species. Journal of Phytopathology, 159, 328, 2011.
111. VEACH A.M., STOKES C.E., KNOEPP J., JUMPPONEN A., BAIRD R. Fungal communities and functional guilds shift along an elevational gradient in the southern appalachian mountains. Microbial Ecology, 76, 1, 2017.

112. TIAN Q., TANIGUCHI T., SHI W.Y., LI G.Q., YAMANAKA N., DU S. Land-use types and soil chemical properties influence soil microbial communities in the semiarid Loess Plateau region in China. Scientific Reports, 7, 45289, 2017.

113. HOLDEN S.R., TRESEDER K.K. A meta-analysis of soil microbial biomass responses to forest disturbances. Frontiers in Microbiology, 4, 163, 2013.

114. MUELLER R.C., RODRIGUES J.L.M., NÜSSLEIN K., BOHANNAN B.J.M. Land use change in the Amazon rain forest favours generalist fungi. Functional Ecology, 30, 1845, 2016

115. ARAÚJO A.S.F., CESARZ S., LEITE L.F.C., BORGES C., TSAI S., VEISENHAUER N. Soil microbial properties and temporal stability in degraded and restored lands of Northeast Brazil. Soil Biology and Biochemistry, 66, 175, 2013.

116. GARCIA-FRANCO N., MARTÍNEZ-MENA M., GOBERNA M., ALBALADEJO J. Changes in soil aggregation and microbial community structure control carbon sequestration after afforestation of semiarid shrublands. Soil Biology and Biochemistry, 87, 110, 2015.

117.EHRENFELD J.G., RAVIT B., ELGERSMA K. Feedback in the plant-soil system. Annual Review of Environment and Resources, 30, 75, 2005.

118. MUELLER K.E., EISSENSTAT D.M., HOBBIE S.E., OLEKSYN J., JAGODZINSKI A.M., REICH P.B., CHADWICK O.A., CHOROVER J. Tree species effects on coupled cycles of carbon, nitrogen, and acidity in mineral soils at a common garden experiment. Biogeochemistry, 111, 601, 2012.

119. STEVENSON B.A. Soil carbon characterization and nutrient ratios across land uses on two contrasting soils: Their relationships to microbial biomass and function. Soil Biology and Biochemistry, 97, 50, 2016.

120. LI Y.C., LI Y.F., CHANG S.X., XU Q.F., GUO Z.Y., GAO Q., QIN Z.Y., YANG Y.F., CHEN J.H., LIANG X. Bamboo invasion of broadleaf forests altered soil fungal community closely linked to changes in soil organic C chemical composition and mineral $\mathrm{N}$ production. Plant and Soil, 418, 507, 2017.

121. YUAN Y., DAI X., XU M., WANG H.M., FU X.L., YANG F.T. Responses of microbial community structure to land-use conversion and fertilization in southern China. European Journal of Soil Biology, 70, 1, 2015.

122. DANG P., YU X., LE H., LIU J., SHEN Z., ZHAO Z. Effects of stand age and soil properties on soil bacterial and fungal community composition in Chinese pine plantations on the Loess Plateau. PloS One, 12, e0186501, 2017. 
